Title: Decrease of $\mathrm{D}_{2}$ receptor binding but increase in $\mathrm{D}_{2}$ stimulated $\mathrm{G}$ protein activation, dopamine transporter binding and behavioural sensitisation in brains of mice treated with a chronic escalating dose "binge" cocaine administration paradigm

Authors: A. Bailey, A. Metaxas, J.H. Yoo, T. McGee, I. Kitchen.

Faculty of Health and Medical Sciences, AY building, University of Surrey, Guildford, Surrey, GU2 7XH, UK

Corresponding author: Dr Alexis Bailey

Faculty of Health and Medical Sciences

AY building

University of Surrey

Guildford

Surrey

GU2 7XH, UK

Tel: +44 (0)1483 689701, Fax: +44 (0)1483686401; E.mail: a.bailey@surrey.ac.uk

Number of figures: 6

Number of tables: 0

Number of pages: 27

Number of words in whole manuscript: 10168

Number of words in abstract: 248

Number of words in introduction: 768

Running title: Chronic cocaine and $\mathrm{D}_{2}$ receptors

Keywords: stereotypy, locomotion, $\left[{ }^{35} \mathrm{~S}\right] \mathrm{GTP} \gamma \mathrm{S}$, autoradiography 
Understanding the neurobiology of the transition from initial drug use to excessive drug use has been a challenge in drug addiction. We examined the effect of chronic "binge" escalating dose cocaine administration, which mimics human compulsive drug use, on behavioural responses and the dopaminergic system of mice and compared it to a chronic steady dose $(3 \times 15 \mathrm{mg} / \mathrm{kg} /$ day) "binge" cocaine administration paradigm. Male C57BL/6J mice were injected with saline or cocaine in an escalating dose paradigm for14 days. Locomotor and stereotypy activity were measured and quantitative autoradiographic mapping of $\mathrm{D}_{1}$ and $\mathrm{D}_{2}$ receptors, dopamine transporters, and $\mathrm{D}_{2}$-stimulated $\left[{ }^{35} \mathrm{~S}\right] \mathrm{GTP} \gamma \mathrm{S}$ binding was performed in the brains of mice treated with this escalating and steady dose paradigm. An initial sensitisation to the locomotor effects of cocaine followed by a dose dependent increase in the duration of the locomotor effect of cocaine was observed in the escalating but not the steady dose paradigm. Sensitisation to the stereotypy effect of cocaine and an increase in cocaineinduced stereotypy score was observed from $3 \times 20$ to $3 \times 25 \mathrm{mg} / \mathrm{kg} /$ day cocaine. There was a significant decrease in $\mathrm{D}_{2}$ receptor density, but an increase in $\mathrm{D}_{2}$ stimulated G- protein activity and dopamine transporter density in the striatum of cocaine treated mice which were not observed in our steady dose paradigm. Our results document that chronic "binge" escalating dose cocaine treatment triggers profound behavioural and neurochemical changes in the dopaminergic system which might underlie the transition from drug use to compulsive drug use associated with addiction, which is a process of escalation. 
Introduction

Cocaine, one of the most commonly abused psychostimulants induces the elevation of extracellular dopamine in the striatum by blocking the dopamine transporter (DAT). The dopaminergic system including $\mathrm{D}_{1}, \mathrm{D}_{2}$ dopamine receptors and DAT has been shown to play a key role in mediating the locomotor, rewarding, reinforcing, sensitising and stereotypic effects of cocaine (for review see Anderson \& Pierce (2005)).

In addition, neurochemical data also supports the presence of interactions between cocaine and the dopaminergic system. There are multiple studies investigating the effect of cocaine on $\mathrm{D}_{1}$ and $\mathrm{D}_{2}$ receptor and DAT density with inconsistent findings with each other. Increases, decreases or no change in $\mathrm{D}_{1}$ receptor binding, $\mathrm{D}_{2}$ receptor binding (Taylor et al., 1979; Goeders \& Kuhar, 1987; Peris et al., 1990; Volkow et al., 1990; Volkow et al., 1993; Berrettini et al., 1994; Unterwald et al., 1994; Maggos et al., 1998; Nader \& Czoty, 2005; Nader et al., 2006; Bailey et al., 2007b) and DAT binding (Kula \& Baldessarini, 1991; Sharpe et al., 1991; Benmansour et al., 1992; Farfel et al., 1992; Alburges et al., 1993; Cass et al., 1993; Hurd \& Herkenham, 1993; Little et al., 1993; Pilotte et al., 1994; Staley et al., 1994; Wilson et al., 1994a; Wilson et al., 1994b; Hitri et al., 1996; Pilotte et al., 1996; Kunko et al., 1997; Maggos et al., 1997; Little et al., 1998a; Little et al., 1999; Bailey et al., 2007b) have been reported. The lack of concordance in the above studies may arise from differences in treatment paradigms (varying doses, schedule and route of administration), length of withdrawal of receptor measurement in relation to the last cocaine injection and/or ligands used to quantify receptors and DAT. Nonetheless, a decrease in $\mathrm{D}_{2}$ availability as measured with positron emission tomography (PET) in cocaine abstinent humans, non human primates and rats has been repeatedly and consistently observed (Volkow et al., 1990; Volkow et al., 
1993; Tsukada et al., 1996; Maggos et al., 1998; Nader \& Czoty, 2005; Nader et al., 2006)

and is thought to be associated with vulnerability to the reinforcing effects of drugs of abuse.

The aim of our study is to characterise the behavioural and neurochemical effect of cocaine on the dopaminergic system of mice treated with an escalating dose "binge" cocaine administration paradigm which closely mimics common features of human cocaine abuse and to compare that with those of traditionally used chronic steady dose "binge" cocaine administration paradigm. A common feature of human cocaine abuse is the development, over time, of tolerance to the reinforcing effects of cocaine, which results in administration of increasing doses of cocaine (Koob \& Kreek, 2007). Indeed, novel animal models of excessive drug taking in dependent animals have recently been developed which demonstrate that rats which are trained to self administer cocaine over a long time, display a number of behavioural patterns consistent with those commonly observed in human cocaine addicts, including a progressive escalation in drug consumption, elevated drug-directed behaviours during extinction/abstinence and increased susceptibility to cocaine induced relapse which are thought to be related to the transition to cocaine addiction . Recent studies have also shown dramatic dysregulation of brain reward pathways (Ahmed \& Koob, 1998; , 1999; Ahmed et al., 2003; Ahmed \& Koob, 2004), activation of brain stress systems in the extended amygdala (Zorrilla et al., 2001; Mantsch et al., 2003) and profound changes in the $\mu$ - (MOP-r) and $\kappa-$ (KOP-r) opioid receptors systems (Bailey et al., 2005; Schlussman et al., 2005; Bailey et al., 2007a) in animal models of escalating "binge" cocaine administration. This study was designed in order to investigate the effects of this novel chronic escalating dose cocaine administration paradigm on locomotion and stereotypy and on the levels of DAT, $\mathrm{D}_{1}, \mathrm{D}_{2}$ receptor binding and $\mathrm{D}_{2}$ stimulated G- protein activity in different brain regions of C57BL/6J mice brains and to compare it with traditionally used steady dose administration paradigms. The results would give us an insight of possible behavioural and neurochemical changes 
taking place in the dopaminergic system which might underlie the transition from drug use to compulsive drug use associated with addiction, which is a process of escalation. In addition, this is the first study which investigated the effect of chronic cocaine use on $D_{2}$ receptor $G$ protein activity with the use of quinerolane stimulated $\left[{ }^{35} \mathrm{~S}\right] \mathrm{GTP} \gamma \mathrm{S}$ autoradiography. These results, which may indeed differ from those obtained with $\mathrm{D}_{2}$ receptor binding, may provide important information on the biochemical basis of the behavioural sensitisation properties of cocaine.

Materials and Methods

Animals and chronic cocaine treatment

6-8 week old C57BL/6J mice, 20-25 g, were studied. Mice were housed individually in a temperature-controlled room, with a $12 \mathrm{~h}$ light/dark schedule. Food and water were available ad libitum. All animals were weighed daily throughout the study. After 7 days of acclimatisation, intraperitoneal (i.p.) injections of either saline $(1 \mathrm{ml} / \mathrm{kg})$ or cocaine were then administered in an escalating or steady dose "binge" paradigm to mimic a common pattern of self-administration in human cocaine abusers (Tsukada et al, 1996). Animals in the escalating dose group received $15 \times 3 \mathrm{mg} / \mathrm{kg} /$ day on days $1-4,20 \times 3 \mathrm{mg} / \mathrm{kg} /$ day on days $5-8$, $25 \times 3 \mathrm{mg} / \mathrm{kg} /$ day on days $9-12$, and $30 \times 3 \mathrm{mg} / \mathrm{kg} /$ day on days 13 and 14 . For animals treated with a chronic steady dose "binge" administration paradigm, 15 x $3 \mathrm{mg} / \mathrm{kg} / \mathrm{day}$ were administered for 14 days. Three i.p. injections ( $1 \mathrm{~h}$ apart) were administered daily, with the first injection 60 min after the start of the light cycle. Animals were randomized into four groups of 6-12. Each group received either saline or cocaine injections for 14 days. Thirty minutes after the last injection, animals were killed by decapitation after a 15 second exposure to $\mathrm{CO}_{2}$. Brains were rapidly removed and frozen by immersion for 30 seconds in isopentane 
cooled to $-35^{\circ} \mathrm{C}$. All studies were performed in accordance with protocols approved by the Home Office (Animals Act 1986) UK.

Cocaine-induced locomotor activity

Locomotor activity was measured by the use of 12 motility chambers $(40 \mathrm{~cm}$ length $\mathrm{x} 20 \mathrm{~cm}$ wide x $20 \mathrm{~cm}$ height) (Linton Instrumentation, Norfolk, UK). Each cage had two sets of 16 photocells located at right angles to each other, projecting horizontal infrared beams $2.5 \mathrm{~cm}$ apart and 1 and $6 \mathrm{~cm}$ above the cage floor. The protocol for locomotor testing was a slight modification of that used by Heidbreder et al. (1998). When mice were tested in the activity chambers, they were habituated for 60 min after which they received an i.p. injection of saline or cocaine. The animals were then returned immediately to the chambers where locomotor activity was assessed for $60 \mathrm{~min}$. The mice received a second and third injection of saline or cocaine $60 \mathrm{~min}$ and $120 \mathrm{~min}$ respectively after the first one and then returned immediately to the chambers where locomotor activity was assessed for $60 \mathrm{~min}$. The locomotor activity for each mouse after each of the three daily injections of saline or cocaine was monitored daily for a period of 14 days. Locomotor activity was defined as the activity from measurement of sequential infrared beam breaks, recorded every $5 \mathrm{~min}$, beginning immediately after placing the animals in the cage following an injection of saline or cocaine and continued for a $60 \mathrm{~min}$ period. For measurement of basal activity, mice were habituated for $60 \mathrm{~min}$ in the motility boxes prior to injections. Another group of mice were treated with 1 day acute "binge" cocaine administration protocol in order to compare the locomotor activity of mice at the end of the chronic escalating dose "binge" cocaine administration protocol with those treated acutely for 1 day with "binge" cocaine. Mice received three i.p. injections ( $1 \mathrm{~h}$ apart) of cocaine (30 x $3 \mathrm{mg} / \mathrm{kg} / \mathrm{day})$ for only 1 day and locomotor activity was measured for $60 \mathrm{~min}$ after each injection. 


\section{Cocaine-induced stereotypy}

All mice receiving either saline or cocaine were videotaped twenty minutes after each injection for $30 \mathrm{sec}$. Videotapes were later rated for stereotypy by a trained observer blind as to the animal's treatment group. The rating was based on a slight adaptation of the scale used by Schlussman et al., (2003) and consisted of a graded scale of drug induced behaviours: 1) asleep, inactive; 2) alert, actively grooming; 3) increased sniffing (occasional light sniffing, often while exploring the cage); 4) intermittent rearing and sniffing (two or three rears in a 20s period, with sniffing frequently at the apex of the rear); 5) increased locomotion; 6) intense sniffing in one location (rapid sniffing, often with head down is the predominant behaviour displayed); 7) continuous pivoting and sniffing (no rearing, no locomotion); 8) intermittent rearing and sniffing (intermittent up and down rearing behaviour with locomotion); 9) maintained rearing and sniffing (animal remains up on hind legs throughout most of the observed period); 10) splayed limbs. Each animal received a single score following each injection, which corresponded to the specific stereotypic behaviour predominantly observed during the $30 \mathrm{sec}$ observation period. The stereotypy behaviour of each mouse injected three times daily with saline or cocaine was scored every day for the 14 days duration of the study. The median stereotypy score of each mouse on each day was used for later analysis.

$\mathrm{D}_{1}, \mathrm{D}_{2}$ dopamine receptor and dopamine transporter (DAT) autoradiography

Animals treated with the escalating dose paradigm were killed 30 min following the last injection of saline or cocaine on day 14 of the study and the brains were immediately removed, quickly frozen in ispentane $\left(-35^{\circ} \mathrm{C}\right)$ and stored at $-80^{\circ} \mathrm{C}$ until sectioning. 
Quantitative autoradiography was performed as detailed previously for $\mathrm{D}_{1}, \mathrm{D}_{2}$ dopamine receptor binding (Lena et al., 2004) and DAT binding (Javitch et al., 1985) using the general procedures of Kitchen et al. (1997). Adjacent $20 \mu \mathrm{m}$ coronal sections were cut at a interval of $300 \mu \mathrm{m}$ from chronic "binge" saline or cocaine treated mice brains for the determination of total and non-specific binding of $\left[{ }^{3} \mathrm{H}\right] \mathrm{SCH}-23390$ (containing $1 \mu \mathrm{M}$ mianserin in order to block 5- $\mathrm{HT}_{2}$ and 5-HT 1 receptor binding sites), $\left[{ }^{3} \mathrm{H}\right]$ raclopride and $\left[{ }^{3} \mathrm{H}\right]$ mazindol at $\mathrm{D}_{1}, \mathrm{D}_{2}$ dopamine receptor and DAT, respectively. Ligand concentrations were 3-4 x $\mathrm{K}_{\mathrm{d}}$ with all ligands used at a concentration of $4 \mathrm{nM}$. Non-specific binding (NSB) was defined in the presence of cis-flupenthixol $(10 \mu \mathrm{M})$, sulpiride $(10 \mu \mathrm{M})$, or unlabelled mazindol $(10 \mu \mathrm{M})$ for $\left[{ }^{3} \mathrm{H}\right] \mathrm{SCH}-23390,\left[{ }^{3} \mathrm{H}\right]$ raclopride and $\left[{ }^{3} \mathrm{H}\right]$ mazindol binding respectively. Following binding for a period of $90 \mathrm{~min}, 60 \mathrm{~min}$ or $45 \mathrm{~min}$ for $\mathrm{D}_{1}, \mathrm{D}_{2}$ dopamine receptor and DAT binding respectively, and washing in ice cold buffer $\left(6 \times 1\right.$ min for $\mathrm{D}_{1}$ and $\mathrm{D}_{2}$ dopamine receptor binding and 2x1 min for DAT binding), the slides were apposed to MR film (Kodak) for 4 weeks. Sections from chronic "binge" saline and cocaine treated mice were processed together in a paired protocol. Films were developed using 50\% Kodak D19 developer. Quantitative analysis of brain receptors was performed as detailed previously (Kitchen et al., 1997; Lena et al., 2004). Using an MCID image analyser (Image Research, Canada), brain structures were identified using the mouse brain atlas of Franklin and Paxinos (1997). The following structures were analysed by sampling 5-10 times with a box tool: cortex $(8 \times 8 \mathrm{~mm})$ and olfactory tubercle $(6 \times 6 \mathrm{~mm})$. All the other areas were analysed using freehand drawing tool. The regions analysed include cingulate cortex, nucleus accumbens core, nucleus accumbens shell, olfactory tubercle, dorsal endopiriform, dorsolateral caudate putamen, dorsomedial caudate putamen, ventomedial caudate putamen, ventrolateral caudate putamen, lateral septum and medial septum. 
Quinelorane-stimulated $\left[{ }^{35} \mathrm{~S}\right] \mathrm{GTP} \gamma \mathrm{S}$ autoradiography

Quinerolane-stimulated $\left[{ }^{35} \mathrm{~S}\right] \mathrm{GTP} \gamma \mathrm{S}$ autoradiography was performed essentially as described by Newman-Tancredi et al., (2001). Coronal sections (20 $\mu \mathrm{m}$ thick) were cut in a cryostat at a interval of $300 \mu \mathrm{m}$ from the same chronic "binge" escalating dose treated C57BL/6J mice or chronic saline treated mice used for the receptor binding autoradiography described in the previous section for the determination of basal, quinelorane-stimulated $\left[{ }^{35} \mathrm{~S}\right] \mathrm{GTP} \gamma \mathrm{S}$ binding, raclopride reversal of quinelorane-stimulated $\left[{ }^{35} \mathrm{~S}\right] \mathrm{GTP} \gamma \mathrm{S}$ binding, and non-specific binding. The same protocol was carried out in brains of mice treated with a chronic steady dose cocaine administration paradigm. Sections were preincubated in assay buffer $(50 \mathrm{mM}$ Tris/ $\mathrm{HCl}, 3 \mathrm{mM} \mathrm{MgCl} 2.6 \mathrm{H}_{2} \mathrm{O}, 0.2 \mathrm{mM} \mathrm{EGTA}, 100 \mathrm{mM} \mathrm{NaCl}, \mathrm{pH} 7.4$ at $25^{\circ} \mathrm{C}$ ) for $10 \mathrm{~min}$. Sections were then incubated in assay buffer containing $2 \mathrm{mM} \mathrm{GDP}, \mathrm{pH} 7.4$ at $25^{\circ} \mathrm{C}$ for 15 min. $\mathrm{D}_{2}$ receptor agonist stimulated activity was determined by incubating the sections in $\left[{ }^{35} \mathrm{~S}\right] \mathrm{GTP} \gamma \mathrm{S}(0.04 \mathrm{nM})$ with the selective $\mathrm{D}_{2}$ receptor agonist quinelorane $(100 \mu \mathrm{M})$ for 2 hours in assay buffer containing $2 \mathrm{mM}$ GDP. Basal G-protein activity was determined by incubating the sections in $\left[{ }^{35} \mathrm{~S}\right] \mathrm{GTP} \gamma \mathrm{S}$ in the presence of GDP $(2 \mathrm{mM})$ and in the absence of the agonist. Non-specific binding was assessed by incubating sections in $\left[{ }^{35} \mathrm{~S}\right] \mathrm{GTP} \gamma \mathrm{S}$ in assay buffer containing $2 \mathrm{mM}$ GDP in the presence of $10 \mu \mathrm{M}$ unlabelled GTP $\gamma \mathrm{S}$. Reversal of quinelorane-stimulated $\left[{ }^{35} \mathrm{~S}\right] \mathrm{GTP} \gamma \mathrm{S}$ binding was determined by incubating sections in $\left[{ }^{35} \mathrm{~S}\right] \mathrm{GTP} \gamma \mathrm{S}$ in the presence of quinelorane $(100 \mu \mathrm{M})$ and raclopride $(10 \mu \mathrm{M})$ in assay buffer containing $2 \mathrm{mM}$ GDP. After incubation for $2 \mathrm{~h}$, slides were rinsed twice for $3 \mathrm{~min}$ in icecold buffer $\left(50 \mathrm{mM}\right.$ Tris/ $\mathrm{HCl}, \mathrm{pH} 7.4$ at $\left.0^{\circ} \mathrm{C}\right)$ followed by one rinse in de-ionised water. Slides were then dried for $2 \mathrm{~h}$ in a cold air stream and drying was continued for a further 2 days using anhydrous calcium sulfate (Drierite, BDHChemicals, Poole, UK). Sections from the brains of chronic cocaine treated mice and chronic saline treated mice were apposed to Kodak MR films (Amersham International plc, Buckinghamshire, UK) together with $\left[{ }^{14} \mathrm{C}\right]$ 
standards (Amersham) for 3 days. Quantitative analysis of optical density was performed as detailed previously (Schroeder et al., 2003) using $\left[{ }^{14} \mathrm{C}\right]$ standards. For each brain region examined, $\left[{ }^{35} \mathrm{~S}\right] \mathrm{GTP} \gamma \mathrm{S}$ binding was calculated by first subtracting the optical density of NSB sections from the optical density of agonist-stimulated, reversal of agonist stimulated or basal binding sections. The regions analysed include nucleus accumbens core, nucleus accumbens shell, olfactory tubercle, dorsolateral caudate putamen, dorsomedial caudate putamen, ventomedial caudate putamen, ventrolateral caudate putamen, lateral septum and medial septum.

\section{Statistics}

Cocaine-induced locomotor activity in 5 min data collection bins was analysed by two-way analysis of variance (ANOVA) (treatment and day) with repeated measures for day, followed by post hoc Newman-Keuls test. Values were expressed as mean \pm S.E.M of total activity per 5 min bin. The median stereotypy score of each animal on each day was used as the raw data for subsequent analysis. Stereotypy behaviour was analysed by mean \pm S.E.M of daily median stereotypy score of saline or chonic cocaine-treated mice. The statistics approach used in this case was two-way ANOVA (for factors treatment and day) with repeated measures for day, followed by post hoc Newman-Keuls test. Since the expression of behavioural stereotypy was measured with a behavioural rating scale, non parametric MannWhitney $U$ tests were also used in order to confirm results obtained by the ANOVA. Twoway ANOVA (for factors region and treatment) was used for comparison of quantitative measures (fmol/mg) of $\mathrm{D}_{1}, \mathrm{D}_{2}$ receptors, DAT in brain regions of chronic "binge" saline and cocaine treated mice followed by post hoc least significant difference (LSD) test.

Quinerolane-stimulated $\left[{ }^{35} \mathrm{~S}\right] \mathrm{GTP} \gamma \mathrm{S}$ binding activity in brain sections of mice was calculated as the increase in relative optical density (ROD) above the basal level in each brain region. 
Comparison of quinerolane-stimulated $\left[{ }^{35} \mathrm{~S}\right] \mathrm{GTP} \gamma \mathrm{S}$ binding and reversal of this stimulation in brains of chronic saline and cocaine-treated mice was carried out using two way ANOVA for factors treatment 1 (saline vs cocaine) and treatment 2 (absence of raclopride vs addition of raclopride) followed by Newman-Keuls test. Comparison of quinerolane-stimulated $\left[{ }^{35} \mathrm{~S}\right] \mathrm{GTP} \gamma \mathrm{S}$ binding in the presence and absence of raclopride in each brain region of saline and cocaine-treated mice, was carried out using Student's t-test. Comparison of basal $\left[{ }^{35} \mathrm{~S}\right] \mathrm{GTP} \gamma \mathrm{S}$ binding in chronic saline and cocaine treated brains were carried out using two way ANOVA for factors treatment (cocaine, saline) and region followed by Newman-Keuls post hoc test. Data from all autoradiography experiments were expressed as the mean \pm S.E.M of each experimental group.

Materials

Cocaine $\mathrm{HCl}$ was purchased from Sigma-Aldrich (Dorset, UK); [ $\left.{ }^{3} \mathrm{H}\right] \mathrm{SCH}-23390(70$

$\mathrm{Ci} / \mathrm{mmol}),\left[{ }^{3} \mathrm{H}\right] \mathrm{raclopride}(60.1 \mathrm{Ci} / \mathrm{mmol}),\left[{ }^{3} \mathrm{H}\right]$ mazindol $(20.6 \mathrm{Ci} / \mathrm{mmol})$ and $\left[{ }^{35} \mathrm{~S}\right] \mathrm{GTP} \gamma \mathrm{S}$ (1250 Ci/mmol) were purchased from Perkin Elmer (Bucks, UK); cis flupenthixol, sulpiride, raclopride, quinerolane, GDP, GTP $\gamma \mathrm{S}$ and mazindol were purchased from Sigma-Aldrich.

Results

Locomotor activity during chronic escalating and steady dose "binge" cocaine administration Locomotor activity of naïve C57BL/6J mice (before saline or cocaine treatment) was measured for $60 \mathrm{~min}$ after placement in the locomotor chambers. The last $5 \mathrm{~min}$ of the $60 \mathrm{~min}$ duration on day 1 is shown in Fig. 1. One-way ANOVA, did not show any significant effect on basal locomotor activity between the two groups on day $1(P>0.05)$. Basal locomotor 
activity between the two treatment groups were measured during the 14 days of the study. Greater basal locomotor activity was observed in the cocaine treated group compared to saline on days 2-14 $(P<0.01)$ (Fig. 1).

Locomotor activity of C57BL/6J mice was measured after each of the three hourly daily injections of saline or cocaine $(15-30 \times 3 \mathrm{mg} / \mathrm{kg} /$ day $)$ from day 1 to day 14 of the chronic escalating dose "binge" cocaine treatment (Fig. 1a). Two-way ANOVA showed a significant main effect treatment $(P<0.0001)$ and day $(P<0.0001)$ and treatment $\mathrm{x}$ day interaction $(P<0.0001)$. Mice treated with cocaine had greater locomotor activity compared to saline on all treatment days $(P<0.0001$, Newman-Keuls post hoc test) (Fig.1a). A significant increase in cocaine-induced locomotor activity was observed on day $3(15 \times 3 \mathrm{mg} / \mathrm{kg} /$ day) compared to day $1(15 \times 3 \mathrm{mg} / \mathrm{kg} /$ day $)(P<0.0001)$ indicating the presence of behavioural sensitisation to the locomotor-stimulating effect of cocaine. Moreover an increase in cocaine-induced locomotor activity was observed on day $5(20 \times 3 \mathrm{mg} / \mathrm{kg} /$ day $)$ vs day $1(P<0.0001)$, day $9(25$ x $3 \mathrm{mg} / \mathrm{kg} /$ day) vs day $5(P<0.01)$, and day $13(30 \times 3 \mathrm{mg} / \mathrm{kg} /$ day $)$ vs day $9(P<0.01)$ indicating that the increase in cocaine-induced locomotion is dose dependent. Both the magnitude and the duration of the cocaine response was enhanced on day 3 compared to day 1. However, although the magnitude of the cocaine response did not increase, a dramatic increase in the duration of cocaine-induced hyperactivity was observed following the increase of the cocaine dose from 20 to $25 \mathrm{mg} / \mathrm{kg} / \mathrm{inj}$ and from 25 to $30 \mathrm{mg} / \mathrm{kg} / \mathrm{inj}$ (Fig. 1a). On day 5, activity of the cocaine-injected animals returned to baseline levels 60 min after each of the three cocaine injections. However, on day 13 the activity of cocaine-injected animals remained constantly elevated at its peak magnitude during the whole $60 \mathrm{~min}$ after each of the three cocaine injections (Fig.1a). 
Another group of mice were injected with $30 \times 3 \mathrm{mg} / \mathrm{kg} /$ day cocaine at $1 \mathrm{~h}$ intervals for only 1 day to compare locomotor activity of mice on day $13(30 \times 3 \mathrm{mg} / \mathrm{kg} /$ day) of the escalating dose "binge" cocaine administration and after acute (1 day) "binge" cocaine administration (30 $33 \mathrm{mg} / \mathrm{kg} / \mathrm{day})$. In contrast with the chronic paradigm where the duration of the peak cocaine response persisted for at least 60 min after cocaine administration, the activity of 1 day acute cocaine treated animals $(3 \times 30 \mathrm{mg} / \mathrm{kg})$ returned to baseline $60 \mathrm{~min}$ after each of the three cocaine injections (Fig. 1a).

Other groups of mice were treated with a steady dose $(3 \times 15 \mathrm{mg} / \mathrm{kg} /$ day $)$ cocaine administration protocol for 14 days (Fig. 1b). Cocaine increased locomotor activity compared to saline every day during the 14 day duration of the study $(\mathrm{P}<0.001$, Newman-Keuls post hoc test). A significant increase in cocaine induced locomotor activity was observed on day 3 compared to day $1(\mathrm{P}<0.001)$ which persisted up to day 5 indicating the presence of behavioural sensitisation to the locomotor effect of cocaine (Fig. 1b). A reduction in cocaineinduced locomotor activity was observed on day 9 and day 13 vs day 5 of our chronic steady dose paradigm (Fig. 1b). In contrast to the escalating dose paradigm, the activity of cocaine injected animals returned to baseline levels $60 \mathrm{~min}$ after each of the three cocaine injections every day during the 14 day duration of the study (Fig. 1b).

Stereotypy behaviour during chronic escalating and steady dose "binge" cocaine administration

Stereotypy activity of C57BL/6J mice was scored 20 min after each of the three injections of saline or cocaine every day for the whole duration of the study and the median score of the three daily injections have recorded (Fig. 2). For the escalating dose group, two-way ANOVA showed a significant main effect of treatment $(P<0.0001)$, day $(P<0.0001)$ and 
significant treatment $\mathrm{x}$ day interaction $(P<0.0001)$. Newman-Keuls post hoc test showed that escalating dose "binge" pattern cocaine administration resulted in a significant expression of behavioural stereotypy $(P<0.0001)$ compared to saline controls (Fig. 2a). A significant increase in cocaine-induced stereotypy was observed on day $3(15 \times 3 \mathrm{mg} / \mathrm{kg} /$ day $)$ compared to day $1(15 \times 3 \mathrm{mg} / \mathrm{kg} /$ day $)(P<0.0001)$ indicating the presence of behavioural sensitisation to the stereotypy-stimulating effect of cocaine. Moreover an increase in cocaine-induced stereotypy behaviour was observed on day $5(20 \times 3 \mathrm{mg} / \mathrm{kg} /$ day $)$ vs day $1(P<0.0001)$, day 9 $(25 \mathrm{mg} / \mathrm{kg} /$ day $)$ vs day $5(\mathrm{P}<0.05)$, but not on day $13(3 \times 30 \mathrm{mg} / \mathrm{kg} /$ day $)$ vs day $9(P>0.05)$. As far as the steady dose group is concerned, cocaine increased stereotypy behaviour every day during the 14 day duration of the chronic steady dose ( $3 \times 15 \mathrm{mg} / \mathrm{kg} / \mathrm{day})$ cocaine administration study compared to saline control $(\mathrm{P}<0.001)$ (Fig. 2b). A significant increase in cocaine-induced stereotypy was observed on day 3 compared to day 1 which persisted for the rest of the duration of the study indicating the presence of behavioural sensitisation to the stereotypy stimulatory effect of cocaine (Fig. 2b). In contrast to the escalating dose paradigm, no increase in cocaine-induced stereotypy behaviour was observed on day 9 vs day $5(\mathrm{P}>0.05)$ (Fig. 2b).

$\mathrm{D}_{1}, \mathrm{D}_{2}$ dopamine receptor and dopamine transporter (DAT) autoradiography during chronic escalating dose "binge" cocaine administration

For $\mathrm{D}_{2}$ dopamine receptor binding, two way ANOVA showed a significant main effect of treatment $(P<0.001)$. LSD post hoc test showed significantly lower levels of $\mathrm{D}_{2}$ binding in the dorsolateral, dorsomedial, ventrolateral and ventromedial $(P<0.001)$ areas of the caudate putamen as well as in the nucleus accumbens core and shell $(P<0.05)$ of cocaine-treated mice compared to controls (Figs. 3, 4A). For DAT binding, two way ANOVA also showed a significant main effect of treatment $(P<0.001)$. In contrast to $\mathrm{D}_{2}$ binding, significantly 
higher levels of DAT binding were observed in the nucleus accumbens shell $(P<0.01)$ and core $(P<0.01)$, in the olfactory tubercle $(P<0.01)$ and in all regions the caudate putamen $(P<0.05)$ of chronic cocaine-treated mice compared to saline controls (Figs. 3, 4B). There was no significant treatment effect on $\mathrm{D}_{1}$ binding (Fig. 3, 4C) $(P>0.05)$.

Quinelorane-stimulated $\left[{ }^{35} \mathrm{~S}\right] \mathrm{GTP} \gamma \mathrm{S}$ autoradiography during chronic escalating and steady dose "binge" cocaine administration

Quinerolane $(100 \mu \mathrm{M})$ stimulated $\left[{ }^{35} \mathrm{~S}\right] \mathrm{GTP} \gamma \mathrm{S}$ autoradiography was performed in coronal brain sections of chronic saline or cocaine-treated mice in order to investigate whether there were any alterations in $\mathrm{D}_{2}$ receptor stimulated $\mathrm{G}$ - protein activity after chronic escalating or steady dose "binge" cocaine administration. In saline and cocaine-treated animals, quinerolane-stimulated $\left[{ }^{35} \mathrm{~S}\right] \mathrm{GTP} \gamma \mathrm{S}$ binding was observed in the nucleus accumbens, caudate putamen, tubercle and septum (Figs. 5 and 6). The level of stimulation was weakest in the lateral septum and medial septum (around 15\% over basal) but was over $50 \%$ above basal in the caudate putamen (data not shown). In the escalating dose groups, adjacent sections were also treated with $\left[{ }^{35} \mathrm{~S}\right] \mathrm{GTP} \gamma \mathrm{S}$ in the presence of both quinerolane $(100 \mu \mathrm{M})$ and the selective $\mathrm{D}_{2}$ receptor antagonist raclopride $(10 \mu \mathrm{M})$ in order to investigate whether the stimulation of G- protein binding by quinerolane is $\mathrm{D}_{2}$ receptor dependent. Two-way ANOVA for factors treatment 1 (saline, cocaine) and treatment 2 (raclopride reversal in the presence of raclopride, no raclopride reversal) with repeated measures for the last variable, showed a significant main effect of treatment $2(P<0001)$ and a significant treatment $1 \times$ treatment 2 interaction $(P<0.05)$. Newman-Keuls post hoc test showed that raclopride significantly reversed the stimulation of $\left[{ }^{35} \mathrm{~S}\right] \mathrm{GTP} \gamma \mathrm{S}$ binding in response to quinerolane (Fig.5, 6a) both in saline $(P<0.001)$ and chronic escalating dose cocaine $(P<0.001)$ treated groups. The significant 
reversal effect of raclopride in each individual region can be observed in Fig.6a. Moreover, an overall increase in quinerolane-stimulated $\left[{ }^{35} \mathrm{~S}\right] \mathrm{GTP} \gamma \mathrm{S}$ binding was observed in escalating dose cocaine-treated brains compared to saline controls $(P<0.05$, Newman-Keuls). A significant increase in quinerolane-stimulated $\left[{ }^{35} \mathrm{~S}\right] \mathrm{GTP} \gamma \mathrm{S}$ binding was observed in the nucleus accumbens shell and the ventrolateral area of the caudate putamen of escalating dose cocaine-treated animals compared to saline controls (Fig. 6a) $(P<0.05$, Student's t test). No change in quinerolane-stimulated $\left[{ }^{35} \mathrm{~S}\right] \mathrm{GTP} \gamma \mathrm{S}$ binding was observed in any brain region of chronic steady dose cocaine ( $3 \times 15 \mathrm{mg} / \mathrm{kg} /$ day for 14 days) treated mice compared to saline control ( $\mathrm{P}>0.05)$ (Fig. 6b).

Two-way ANOVA for factors treatment and region of the basal $\left[{ }^{35} \mathrm{~S}\right] \mathrm{GTP} \gamma \mathrm{S}$ data for escalating dose treated animals revealed significantly higher overall levels of basal $\left[{ }^{35} \mathrm{~S}\right] \mathrm{GTP} \gamma \mathrm{S}$ binding in cocaine treated mice brains compared to saline controls $(\mathrm{P}=0.05)$ (data not shown). However, there was no significant increase in basal $\left[{ }^{35} \mathrm{~S}\right] \mathrm{GTP} \gamma \mathrm{S}$ binding in any of the individual regions analysed $(\mathrm{P}>0.05)$. Despite of this, there was still a significant increase in quinerolane stimulated $\left[{ }^{35} \mathrm{~S}\right] \mathrm{GTP} \gamma \mathrm{S}$ binding in cocaine treated brains compared to saline controls. There was no treatment effect in brains on basal G protein activity of steady dose cocaine treated mice compared to saline controls $(\mathrm{P}>0.05)$ (data not shown).

\section{Discussion}

The behavioural results obtained in this study indicate the initial presence of locomotor sensitization to the locomotor effect of cocaine, followed by a dose dependent increase in the duration but not the magnitude of the locomotor activating effect of cocaine. In our locomotor paradigm of chronic "binge" cocaine administration, behavioural sensitisation 
could be reflected by the increase in the magnitude (maximum or peak response) as measured by increased amount of counts at the time point where the counts are maximal (peak counts) or by increased duration of the locomotor effect of cocaine. Indeed in our escalating dose paradigm (see Fig. 1a) an increase in the peak locomotor effect of cocaine in day 3 compared to day 1 and an increase in the duration of the cocaine effect on day 13 (without observing an increase in the peak response to cocaine) compared to day 3 were observed, which is an indication of behavioural sensitisation. However, in our steady dose paradigm, an increase in the peak locomotor effect of cocaine was observed in day 3 compared to day 1 (initial sensitisation), but a decrease in the peak locomotor effect of cocaine was observed in day 13 compared to day 3 without alteration of the duration of the locomotor effect of cocaine, which indicates a lack of sensitisation effect at that time point. These results suggest an increase of behavioural sensitisation on day 13 of our escalating dose cocaine administration paradigm but not in our steady dose paradigm. These results are in agreement with Foltin et al., (2003) who compared the effects of escalating doses of smoked cocaine with a fixed dosing group in humans. They demonstrated a dose-dependent increase in heart rate, blood pressure, ratings of positive drug effect in the escalating dose group and a maintenance of the initial cocaine effect throughout the whole study in the fixed group. Together these results demonstrate that increasing the dose of cocaine during a "binge" of cocaine use can increase the effect of cocaine, but administering the same cocaine dose maintains, but not increases the effect of cocaine suggesting the presence of different neurobiological mechanisms that underlie the transition from drug use to compulsive drug use associated with addiction, which is a process of escalation.

The initial sensitization effect of cocaine observed in our study is in agreement with the development of locomotor sensitization observed in C57BL/6J mice in our study and in others using a 14 day steady dose "binge" pattern $(15 \times 3 \mathrm{mg} / \mathrm{kg} /$ day $)$ cocaine administration 
paradigm (Unterwald et al., 1994; Bailey et al., 2007a), but in contrast with Schlussman et al., (2003) who showed tolerance to the locomotor effect of cocaine in C57BL/6J mice treated the same chronic steady dose "binge" paradigm as above, in their home cage. This discrepancy is likely to be due to the different environment where the drug was administered during the chronic "binge" paradigm (home cage vs novel environment). Indeed, it has been reported that sensitisation is more robust when cocaine is repeatedly administered outside the home cage than in the home cage (Badiani et al., 1995; Browman et al., 1998; Uslaner et al., 2003). As a result, the increase in the duration of cocaine action observed in days 9-14 of our escalating dose paradigm is unlikely to be due to a dose effect rather than sensitization as we did not observe any increase in the duration of the cocaine effect when mice were treated with an acute $3 \times 30 \mathrm{mg} / \mathrm{kg}$ (Fig 1a) or during any day of the 14 day steady dose cocaine ( $3 \times 15$ $\mathrm{mg} / \mathrm{kg} /$ day) administration paradigm. This is in agreement with Daunais and McGinty (1995) who found no differences in the behavioural rating scores of male Wistar rats which received 30 or $60 \mathrm{mg} / \mathrm{kg}$ of cocaine in daily "binges", suggesting that the expression of behavioural activity has reached a maximum at the relatively high dose of $15 \mathrm{mg} / \mathrm{kg} /$ injection. As a result, other factors such as the dysregulation of the dopaminergic system may account for the locomotor effects of chronic "binge" escalating dose cocaine administration.

In accordance with the locomotor activity data, behavioural sensitization to the stereotypy inducing effect of cocaine, followed by an increase in magnitude of stereotypy score on day 9 compared to day 5, but not on day 13 vs day 9 where the stereotypy effect of cocaine seems to reach saturation, was observed in our escalating dose study. An initial sensitisation was observed on day 3 of our steady dose paradigm which persisted throughout the rest of the duration of the study. These findings are in contrast with studies showing a lack of sensitisation to the stereotypy behaviour during an identical 14 day "binge" escalating dose cocaine administration paradigm in rats (Schlussman et al., 2005) and during a 14 day steady 
dose (15 x $3 \mathrm{mg} / \mathrm{kg} /$ day) "binge" cocaine administration in rats (Schlussman et al., 2005) and C57BL/6J mice (Schlussman et al., 2003; Bailey et al., 2007a). This divergence is again likely to be due to the different environment where the drug was administered during the chronic "binge" paradigm reinforcing the importance of home cage vs novel environment.

As discussed above, there is a profound difference in the behavioural effect of cocaine when administered in a chronic "binge" escalating dose $(15-30$ x $3 \mathrm{mg} / \mathrm{kg} /$ day $)$ paradigm compared to a chronic "binge" steady dose $(15 \times 3 \mathrm{mg} / \mathrm{kg} /$ day $)$ paradigm. We hypothesised that these changes might be due to profound alterations in the dopamine neurotransmission during escalation of cocaine administration which may not take place during steady dose administration. In support of this, Ahmed et al., (2003) showed that rats which escalate their intake of cocaine maintain greater levels of dopamine in the nucleus accumbens and are more sensitive to the actions of the selective dopamine antagonist cis-flupenthixol than rats which had limited access to the drug (steady dose) and that this phenomenon is not associated with a change in cocaine pharmacokinetics or efficacy. The above findings support the hypothesis that a decrease in dopamine neurotransmission contributes to escalation of cocaine self administration.

Although there have been numerous studies investigating the effect of chronic cocaine administration on $\mathrm{D}_{1}, \mathrm{D}_{2}$ dopamine receptor and DAT with conflicting results (see introduction), this is the first study which has investigated the effects of cocaine administered in a chronic "binge" escalating dose pattern which more closely mimics human drug abuse, on $\mathrm{D}_{1}, \mathrm{D}_{2}$ dopamine receptor, DAT binding and $\mathrm{D}_{2}$ stimulated $\mathrm{G}$ protein activity. $\mathrm{A}$ significant decrease in $\mathrm{D}_{2}$ receptor density was observed in all regions of the striatum of cocaine-treated mice compared to saline controls. This is in agreement with the consistent finding of a decrease in $\mathrm{D}_{2}$ receptor availability and binding as measured by PET and in vitro 
autoradiography in the brains of cocaine abstinent humans, non human primates and rats (Volkow et al., 1990; Volkow et al., 1993; Moore et al., 1998; Nader et al., 2002; Nader \& Czoty, 2005; Nader et al., 2006) and could reflect receptor downregulation from the exposure to a higher extracellular dopamine concentration due to chronic blockade of dopamine transporters. Moreover, and in accordance with Ahmed et al., (2004), this decrease in $\mathrm{D}_{2}$ receptors may be indicative of a "hypodopaminergic" system which is in need of escalating doses of cocaine to maintain increased levels of dopamine in the nucleus accumbens. Interestingly, our results are in contrast with those from our group (Bailey et al., 2007b) and others (Unterwald et al., 1994) who showed a lack of decrease in $\mathrm{D}_{2}$ receptor binding when using a 14 day steady dose "binge" cocaine ( 15 x $3 \mathrm{mg} / \mathrm{kg} /$ day) administration paradigm, suggesting that cocaine-induced changes in $\mathrm{D}_{2}$ receptors is dependent on the paradigm used (steady vs escalating). This is in agreement with Nader and Czoty, (2005) who showed that duration of exposure and dose of the drug are important factors which affect $\mathrm{D}_{2}$ receptor density in brains of monkeys self administering cocaine.

In order to investigate whether the decrease in $\mathrm{D}_{2}$ receptor binding was of any functional significance, we measured $\mathrm{D}_{2}$ receptor $\mathrm{G}$ protein activity with the use of quinerolane stimulated $\left[{ }^{35} \mathrm{~S}\right] \mathrm{GTP} \gamma \mathrm{S}$ autoradiography in the brains of the same animals in which $\mathrm{D}_{2}$ receptor binding was measured, in order to obtain a completely paired result. In contrast to the $\mathrm{D}_{2}$ receptor density data, an overall significant increase in quinerolane stimulated $\left[{ }^{35} \mathrm{~S}\right] \mathrm{GTP} \gamma \mathrm{S}$ binding was observed in the brains of chronic "binge" escalating dose cocainetreated mice compared to saline controls, with a marked regional significant increase in the nucleus accumbens shell and the ventromedial area of the caudate putamen. No change was observed in quinerolane-stimulated $\left[{ }^{35} \mathrm{~S}\right] \mathrm{GTP} \gamma \mathrm{S}$ binding brains of steady dose cocaine treated mice compared to saline controls in any regions analysed. These results show the importance 
of determining functional activity of receptor systems, demonstrating that downregulation of receptors does not necessarily translate into loss of functional coupling. Indeed, we showed that while no change in $\mu$ - opioid receptor (MOP-r) density was observed in brains of morphine withdrawn mice deficient in the $\mathrm{A}_{2 \mathrm{~A}}$ receptor compared to wild types, there was an enhancement in MOP-r stimulated $\left[{ }^{35} \mathrm{~S}\right] \mathrm{GTP} \gamma \mathrm{S}$ binding in the nucleus accumbens of these mice (Bailey et al., 2004). The increase in $\mathrm{D}_{2}$ receptor coupling to $\mathrm{G}$ protein activity in the brains of chronic "binge" escalating cocaine treated mice suggests that chronic cocaine treatment increases $D_{2}$ receptor sensitivity by increasing $D_{2}$ receptor coupling rather than increasing $\mathrm{D}_{2}$ receptor surface receptors. This is accordance with studies showing that locomotor and stereotypy responses to $\mathrm{D}_{2}$ receptor agonists are greater in cocaine-sensitized rats than in saline treated controls (Ujike et al., 1990; De Vries et al., 2002). In addition our results are in agreement with Seeman et al. (2007) who showed a 2.2 fold increase in the guanine-nucleotide-sensitive component of $\mathrm{D}_{2}$ receptor binding in amphetamine sensitized rats. This confirms the increase in $\mathrm{D}_{2}$ receptor $\mathrm{G}$ protein activity in psychostimulant sensitized animals with another psychostimulant, by a different method and ligands and in different species, even though the total $\mathrm{D}_{2}$ receptor density is significantly decreased. The maintained elevated locomotor activity observed on day 13 of the escalating dose paradigm could partially be explained by the increase in $\mathrm{D}_{2}$ receptor activity and thus the increase in $\mathrm{D}_{2}$ receptor sensitivity observed in these mice. This is the first study which provides biochemical evidence for the increase of sensitivity of $\mathrm{D}_{2}$ receptors following chronic escalating dose "binge" cocaine treatment despite the decrease of $\mathrm{D}_{2}$ receptor density.

The increase in $D_{2}$ receptor coupling to $G$ protein in our study is unlikely to be due to increase in pertussis toxin sensitive $G$ protein $\left(G_{i / o}\right)$ which couples to $D_{2}$ receptors as it has been shown that cocaine decreases $\mathrm{G}_{\mathrm{i} / \mathrm{o}}$ in the nucleus accumbens of rats (Nestler et al., 1990). Alterations of other factors downstream of the receptor affecting $G_{i / 0}$ coupling to $D_{2}$ receptors in response 
to chronic cocaine administration might play an important role. For instance alterations in Gprotein coupled receptor kinase 6 (GRK6), which is known to be involved in $\mathrm{D}_{2}$ receptor desensitisation, might be a possible candidate, as enhanced $G$ protein coupling to $\mathrm{D}_{2}$ receptors and augmented locomotor responses to cocaine was observed in mice deficient in GRK6 (Gainetdinov et al., 2003). The mechanism involved in the increase in $\mathrm{D}_{2}$ receptor coupling in escalating dose cocaine treated mice is not clear. It could be the result of a homeostatic response to the decreased $\mathrm{D}_{2}$ receptor numbers observed after chronic cocaine administration. Another possibility is that the increase in presynaptic $\mathrm{D}_{2}$ receptor coupling would result in reducing dopamine release and thus contribute to the "hypodopaminergic" state which is indicative of escalating dose cocaine administered animals.

As quinerolane has been shown to bind to $\mathrm{D}_{2}$ receptors as well as $\mathrm{D}_{3}$ receptors with high affinity (Gackenheimer et al., 1995), there is a possibility that the increase in quinerolane stimulated $\left[{ }^{35} \mathrm{~S}\right] \mathrm{GTP} \gamma \mathrm{S}$ binding reflects increases of not only $\mathrm{D}_{2}$ receptor $\mathrm{G}$ protein activity but also of $\mathrm{D}_{3}$ receptors. However, the fact that quinerolane-induced stimulation was observed in regions of known high $\mathrm{D}_{2}$ receptor density and not in regions of high $\mathrm{D}_{3}$ receptor density (islands of Calleja, the bed nucleus of stria terminallis), and that quinerolane stimulation was completely abolished by the highly selective $\mathrm{D}_{2}$ receptor antagonist raclopride, indicate that the increase in quinerolane stimulated $\left[{ }^{35} \mathrm{~S}\right] \mathrm{GTP} \gamma \mathrm{S}$ binding observed in our study is attributed to $D_{2}$ receptors rather than $D_{3}$ receptors. In support of this, previous behavioural and biochemical data showed that selective $\mathrm{D}_{3}$ and $\mathrm{D}_{4}$ antagonists did not block quinerolane induced turning behaviour and $\left[{ }^{35} \mathrm{~S}\right] \mathrm{GTP} \gamma \mathrm{S}$ binding in the rat (Newman-Tancredi et al., 2001).

In addition to the opposite changes in $\mathrm{D}_{2}$ receptor binding and activity observed in our study, a significant increase in DAT binding was observed in the striatum of mice treated with a 
chronic "binge" escalating dose cocaine administration paradigm. This is in agreement with studies showing increases in the DAT binding and/or dopamine uptake in brains of human cocaine abusers (Staley et al., 1994; Little et al., 1998b; Little et al., 1999; Mash et al., 2002), in rodents which self administer cocaine (Wilson et al., 1994a) and in rodents which have been chronically treated with cocaine (Pilotte et al., 1994; Claye et al., 1995; Hitri et al., 1996). This increase in the numbers of DAT following chronic cocaine administration might reflect a compensatory change to modify synaptic dopamine concentration in the striatum and to maintain dopaminergic neurotransmission at more normal levels. Indeed, as cocaine elevates dopamine by blocking reuptake into the presynaptic terminal, one way to compensate for the effect of cocaine would be to enhance the uptake and transport of dopamine across the dopaminergic presynaptic membrane by increasing DAT density. Such increases in DAT might not only contribute to the dopaminergic deficit believed to occur in the brain of escalating dose cocaine self administration (Ahmed et al., 2003; Ahmed \& Koob, 2004), but might also contribute to cocaine withdrawal symptoms that cocaine abusers experience such as depression and suicidability and thus might sustain the rewarding effect of cocaine bingeing (Little et al., 1999).

A possible mechanism by which chronic escalating dose cocaine administration might increase DAT density is by the activation of the $\mathrm{D}_{2}$ receptors observed in our study. While Parson et al., (1993) demonstrated that D2 receptor antagonists prevents the upregulation of dopamine uptake that results from chronic intermittent cocaine administration, Mayfield and Zahniser., (2001) found that activation of $\mathrm{D}_{2}$ receptors via the $\mathrm{G}_{\mathrm{i} / \mathrm{o}}$ coupling results in an increased number of DAT sites. Interestingly, in contrast to our data, a lack of change in DAT density was observed in C57BL/6J mice treated with a 14 day "binge" steady dose ( $15 \mathrm{x}$ $3 \mathrm{mg} / \mathrm{kg} /$ day) administration protocol (Bailey et al., 2007b). 
In contrast with DAT and $\mathrm{D}_{2}$ receptor density and activity, there was no change in $\mathrm{D}_{1}$ receptor density in the brains of escalating dose cocaine treated mice compared to saline controls. Although there is a large body of literature suggesting an important role for $\mathrm{D}_{1}$ receptors in the expression of cocaine sensitisation (for review see Anderson and Pierce (2005), Spanagel (1995) and Unterwald et al., (1994), the lack of $\mathrm{D}_{1}$ receptor changes in our study suggests that $\mathrm{D}_{1}$ receptor numbers might not play a role in our escalating pattern of cocaine administration. These results are in accordance with a previous study in this lab (Bailey et al., 2007b) which failed to find any significant change in $\mathrm{D}_{1}$ receptor binding in a 14 day steady dose "binge" cocaine administration paradigm. However, a lack of change in $\mathrm{D}_{1}$ receptor numbers does not exclude changes in $\mathrm{D}_{1}$ receptor $\mathrm{G}$ protein coupling and in second messenger transmission downstream from the receptor. Moreover, $\mathrm{D}_{1}$ receptors might play an important role in the initiation (early stage) of sensitisation, but not in the later stage of compulsive escalating drug abuse.

Finally, the lack of changes in $\mathrm{D}_{2}, \mathrm{D}_{2}$ stimulated $\left[{ }^{35} \mathrm{~S}\right] \mathrm{GTP} \gamma \mathrm{S}$ and DAT binding in the steady dose cocaine treated mice together with the profound changes observed in $D_{2}, D_{2}$ stimulated $\left[{ }^{35} \mathrm{~S}\right] \mathrm{GTP} \gamma \mathrm{S}$ and DAT binding in the brains of escalating dose cocaine treated mice, suggest the presence of different neurobiological mechanisms that underlie the transition from drug use to compulsive drug use associated with addiction, which is a process of escalation.

Furthermore, our results together with others indicate that our chronic "binge" escalating dose cocaine administration paradigm is a more appropriate model to study drug abuse as both the behavioural and biochemical alterations observed in this model more closely mimics those observed in human cocaine abusers.

Legend to Figure 1. Locomotor activity in $\mathrm{C} 57 \mathrm{BL} / 6 \mathrm{~J}$ mice after saline or cocaine treatment during a chronic "binge" a) escalating dose and b) steady dose administration paradigm. The 
locomotor data were collected daily in 5 min bins following each of the three injections of a 14 day "binge" escalating dose (15-30 x $3 \mathrm{mg} / \mathrm{kg} /$ day, i.p.) or steady dose (15 x $3 \mathrm{mg} / \mathrm{kg} / \mathrm{day}$, i.p.) pattern of cocaine or saline. Representative responses are shown from day 1 , day 3, day 5 and day 13. The locomotor activity of one group of C57BL/6J mice treated for one day with an acute "binge" cocaine administration paradigm $(30 \times 3 \mathrm{mg} / \mathrm{kg} /$ day $)$ is seen in the bottom right corner of the figure. Values are mean \pm S.E.M of 6-12 animals in each group. Two-way ANOVA showed a significant main effect of treatment $(P<0.0001)$, day $(P<0.0001)$ and treatment $\mathrm{x}$ day interaction $(P<0.0001)$ for both escalating and steady dose paradigms. There was an increase in basal locomotion in the cocaine treated groups vs saline control on days 2-14 $(P<0.01)$ on the treatment paradigm in the escalating dose group. Significant asterisks were omitted from the graph for clarity of presentation.

Legend to Figure 2. Daily stereotypy scores in C57BL/6J mice following chronic "binge" a) escalating dose and b) steady dose cocaine administration. The stereotypy score assigned to each animal was based on its median stereotypy score of the three daily injections of "binge" pattern cocaine or saline administration recorded $20 \mathrm{~min}$ after each of injection. Values are mean \pm S.E.M of 6 animals in each group. Two way ANOVA showed a significant main effect of treatment $(P<0.0001)$, day $(P<0.0001)$ and significant treatment $\mathrm{x}$ day interaction $(P<0.0001)$ for both escalating and steady dose treatment. Cocaine administration resulted in a significant expression of behavioural stereotypy $(P<0.0001)$ ${ }^{* * *} \mathrm{P}<0.001$ vs day $1,{ }^{*} \mathrm{P}<0.05$ vs day 5 (Newman-Keuls post hoc test)

Legend to Figure 3. Computer-enhanced autoradiograms of coronal brain sections from chronic "binge" escalating dose cocaine or saline treated C57BL/6J mice. The adjacent sections shown are from the level of the caudate (Bregma $1.10 \mathrm{~mm}$ ). $\mathrm{D}_{1}, \mathrm{D}_{2}$ dopamine receptor and dopamine transporters (DAT) were labelled with $\left[{ }^{3} \mathrm{H}\right] \mathrm{SCH}-23390(4 \mathrm{nM})$, 
$\left[{ }^{3} \mathrm{H}\right]$ raclopride $(4 \mathrm{nM})$ and $\left[{ }^{3} \mathrm{H}\right]$ mazindol $(4 \mathrm{nM})$, respectively. Non-specific binding (NSB) was defined in the presence of cis-flupenthixol $(10 \mu \mathrm{M})$, sulpiride $(10 \mu \mathrm{M})$, or unlabelled mazindol $(10 \mu \mathrm{M})$ for $\left[{ }^{3} \mathrm{H}\right] \mathrm{SCH}-23390,\left[{ }^{3} \mathrm{H}\right]$ raclopride and $\left[{ }^{3} \mathrm{H}\right]$ mazindol binding respectively. The colour bar represents a pseudo-colour interpretation of black and white film images in fmol/mg tissue equivalent. Sections cut from chronically cocaine and saline treated C57BL/6J brains were processed in parallel.

Legend to Figure 4. Quantitative autoradiography of $\mathrm{D}_{1}, \mathrm{D}_{2}$ dopamine receptor and dopamine transporters binding in coronal brain sections from chronic "binge" escalating dose cocaine and saline treated C57BL/6J mice. Data are expressed as the mean specific binding $(\mathrm{fmol} / \mathrm{mg}) \pm$ S.E.M of 5-10 determinants of A) $\left[{ }^{3} \mathrm{H}\right]$ raclopride, B) $\left[{ }^{3} \mathrm{H}\right]$ mazindol and C) $\left[{ }^{3} \mathrm{H}\right] \mathrm{SCH}-23390$ in brain regions of chronically cocaine or saline treated $\mathrm{C} 57 \mathrm{BL} / 6 \mathrm{~J}$ mice. The labelling was carried out on sections from chronically cocaine or saline treated C57BL/6J mice in a completely paired protocol. Specific binding was $>80 \%$ in all regions analysed. Two way ANOVA showed a significant main effect of treatment $(P<0.001)$ for $\left[{ }^{3} \mathrm{H}\right]$ mazindol binding and $\left[{ }^{3} \mathrm{H}\right]$ raclopride binding, but not for $\left[{ }^{3} \mathrm{H}\right] \mathrm{SCH}-23390$ binding. ${ }^{*} P<0.05, * * P<0.01, * * * P<0.001$ vs saline controls (LSD post hoc test). Abbreviations: $\mathrm{CgCx}$, Cingulate cortex; AcbC, Nucleus accumbens core; AcbSh, Nucleus accumbens shell; $\mathrm{Tu}$, Olafactory tubercle; Den, Dorsal endopiriform; DLCPu, Dorsolateral caudate putamen; $\mathrm{DMCPu}$, Dorsomedial caudate putamen; $\mathrm{VMCPu}$, Ventomedial caudate putamen; VLCPu, Ventrolateral caudate putamen; LS, Lateral septum; MS, Medial septum

Legend to Figure 5. Computer-enhanced autoradiograms of coronal brain sections from chronically "binge" escalating dose cocaine and saline treated C57BL/6J mice. The sections shown are from the level of the caudate (Bregma $1.10 \mathrm{~mm}$ ) Sections were preincubated with 
$2 \mathrm{mM}$ GDP and then incubated for $2 \mathrm{~h}$ with $\left[{ }^{35} \mathrm{~S}\right] \mathrm{GTP} \gamma \mathrm{S}(0.04 \mathrm{nM})$ and $2 \mathrm{mM}$ GDP (basal), $\left[{ }^{35} \mathrm{~S}\right] \mathrm{GTP} \gamma \mathrm{S}(0.04 \mathrm{nM})$ and $2 \mathrm{mM}$ GDP in the presence of quinerolane $(100 \mu \mathrm{M})$ (quinerolane stimulated $\left.\left[{ }^{35} \mathrm{~S}\right] \mathrm{GTP} \gamma \mathrm{S}\right),\left[{ }^{35} \mathrm{~S}\right] \mathrm{GTP} \gamma \mathrm{S}(0.04 \mathrm{nM})$ and $2 \mathrm{mM}$ GDP in the presence of quinerolane $(100 \mu \mathrm{M})$ and raclopride $(10 \mu \mathrm{M})$ (reversal of quinerolane stimulated $\left.\left[{ }^{35} \mathrm{~S}\right] \mathrm{GTP} \gamma \mathrm{S}\right)$ or with $\left[{ }^{35} \mathrm{~S}\right] \mathrm{GTP} \gamma \mathrm{S}(0.04 \mathrm{nM})$ and $2 \mathrm{mM}$ GDP in the presence of $10 \mu \mathrm{M}$ unlabelled GTP $\gamma \mathrm{S}$ (non-specific binding, NSB). The colour bar represents a pseudo-colour interpretation of relative black and white film images. Sections cut from chronically "binge" saline and cocaine treated mice brains were processed in parallel.

Legend to Figure 6. Quinerolane stimulated $\left[{ }^{35} \mathrm{~S}\right] \mathrm{GTP} \gamma \mathrm{S}$ binding in coronal brain sections from chronically "binge" a) escalating dose and b) steady dose cocaine and saline treated C57BL/6J mice. Data are expressed as mean \pm S.E.M $(n=6-12)$ of $\left[{ }^{35} \mathrm{~S}\right] \mathrm{GTP} \gamma \mathrm{S}$ stimulation expressed as increase in relative optical density (ROD) above basal. Two way ANOVA showed a significant main effect of raclopride (reversal) $(P<0.001)$ and a significant raclopride $\mathrm{x}$ treatment (saline, cocaine) interaction $(P<0.05)$ in the escalating dose group. There was an overall increase in quinerolane stimulated $\left[{ }^{35} \mathrm{~S}\right] \mathrm{GTP} \gamma \mathrm{S}$ binding in the escalating dose cocaine treated mice compared to saline controls $(P<0.05)$. No cocaine effect was observed in the steady dose group.

${ }^{\#} P<0.05,{ }^{\# \#} P<0.01,{ }^{\# \#} P<0.001$ vs $D_{2}$ stimulated $\left[{ }^{35} \mathrm{~S}\right] \mathrm{GTP} \gamma \mathrm{S}$ binding in the cocaine group; ${ }^{*}$ $P<0.05$ vs $\mathrm{D}_{2}$ stimulated $\left[{ }^{35} \mathrm{~S}\right] \mathrm{GTP} \gamma \mathrm{S}$ binding in the saline group (Student's $\mathrm{t}$ test).

Abbreviations: AcbC, accumbens core; AcbSh, accumbens shell; Tu, olfactory tubercle; $\mathrm{DLCPu}$, Dorsolateral caudate putamen; $\mathrm{DMCPu}$, Dorsomedial caudate putamen; VMCPu, Ventomedial caudate putamen; VLCPu, Ventrolateral caudate putamen; LS, Lateral septum; MS, Medial septum 
Acknowlegements: Supported by the European Commission EC (LSHM-CT-2004-005166), the Korea Science and Engineering Foundation (2005-215-E00003) and Merck, Sharp and Dohme.

Abbreviations: AcbC, Nucleus accumbens core; AcbSh, Nucleus accumbens shell; ANOVA, analysis of variance; $\mathrm{CgCx}$, Cingulate cortex; DAT, dopamine transporter; Den, Dorsal endopiriform; DLCPu, Dorsolateral caudate putamen; DMCPu, Dorsomedial caudate putamen, $\mathrm{G}_{\mathrm{i} / \mathrm{o}}$, G- ptrotein; KOP-r, $\kappa$ - opioid receptors, LS, Lateral septum; MOP-r, $\mu$ opioid receptors, MS, Medial septum; NSB: non specific binding, PET, positron emission tomography; $\mathrm{Tu}$, Olafactory tubercle; $\mathrm{VMCPu}$, Ventomedial caudate putamen; VLCPu, Ventrolateral caudate putamen

References

Achat-Mendes, C., Anderson, K.L. \& Itzhak, Y. (2003) Methylphenidate and MDMA adolescent exposure in mice: long-lasting consequences on cocaine-induced reward and psychomotor stimulation in adulthood. Neuropharmacology, 45, 106-115.

Ahmed, S.H. \& Koob, G.F. (1998) Transition from moderate to excessive drug intake: change in hedonic set point. Science, 282, 298-300.

Ahmed, S.H. \& Koob, G.F. (1999) Long-lasting increase in the set point for cocaine selfadministration after escalation in rats. Psychopharmacology (Berl), 146, 303-312.

Ahmed, S.H. \& Koob, G.F. (2004) Changes in response to a dopamine receptor antagonist in rats with escalating cocaine intake. Psychopharmacology (Berl), 172, 450-454.

Ahmed, S.H., Lin, D., Koob, G.F. \& Parsons, L.H. (2003) Escalation of cocaine selfadministration does not depend on altered cocaine-induced nucleus accumbens dopamine levels. J. Neurochem., 86, 102-113.

Alburges, M.E., Narang, N. \& Wamsley, J.K. (1993) Alterations in the dopaminergic receptor system after chronic administration of cocaine. Synapse, 14, 314-323.

Ambrosio, E., Sharpe, L.G. \& Pilotte, N.S. (1997) Regional binding to corticotropin releasing factor receptors in brain of rats exposed to chronic cocaine and cocaine withdrawal. Synapse, 25, 272-276.

Anderson, S.M. \& Pierce, R.C. (2005) Cocaine-induced alterations in dopamine receptor signaling: implications for reinforcement and reinstatement. Pharmacol. Ther., 106, 389403.

Badiani, A., Browman, K.E. \& Robinson, T.E. (1995) Influence of novel versus home environments on sensitization to the psychomotor stimulant effects of cocaine and amphetamine. Brain Res., 674, 291-298. 
Bailey, A., Davis, L., Lesscher, H.M., Kelly, M.D., Ledent, C., Hourani, S.M. \& Kitchen, I. (2004) Enhanced morphine withdrawal and $\mu$-opioid receptor G-protein coupling in $\mathrm{A}_{2 \mathrm{~A}}$ adenosine receptor knockout mice. J. Neurochem., 88, 827-834.

Bailey, A., Gianotti, R., Ho, A. \& Kreek, M.J. (2007a) Downregulation of kappa-opioid receptors in basolateral amygdala and septum of rats withdrawn for 14 days from an escalating dose "binge" cocaine administration paradigm. Synapse, 61, 820-826.

Bailey, A., Gianotti, R. \& Kreek, M.J. (2005) Persistent upregulation of $\mu$ - opioid but not adenosine receptors in brains of long term withdrawn escalating dose "binge" cocaine treated rats. Synapse, 57, 160-166.

Bailey, A., Yoo, J.H., Racz, I., Zimmer, A. \& Kitchen, I. (2007b) Preprodynorphin mediates locomotion and D2 dopamine and mu-opioid receptor changes induced by chronic 'binge' cocaine administration. J. Neurochem., 102, 1817-1830.

Benmansour, S., Tejani-Butt, S.M., Hauptmann, M. \& Brunswick, D.J. (1992) Lack of effect of high-dose cocaine on monoamine uptake sites in rat brain measured by quantitative autoradiography. Psychopharmacology (Berl), 106, 459-462.

Berrettini, W.H., Ferraro, T.N., Alexander, R.C., Buchberg, A.M. \& Vogel, W.H. (1994) Quantitative trait loci mapping of three loci controlling morphine preference using inbred mouse strains. Nat. Genet., 7, 54-58.

Browman, K.E., Badiani, A. \& Robinson, T.E. (1998) The influence of environment on the induction of sensitization to the psychomotor activating effects of intravenous cocaine in rats is dose-dependent. Psychopharmacology (Berl), 137, 90-98.

Cass, W.A., Gerhardt, G.A., Gillespie, K., Curella, P., Mayfield, R.D. \& Zahniser, N.R. (1993) Reduced clearance of exogenous dopamine in rat nucleus accumbens, but not in dorsal striatum, following cocaine challenge in rats withdrawn from repeated cocaine administration. J. Neurochem., 61, 273-283.

Claye, L.H., Akunne, H.C., Davis, M.D., DeMattos, S. \& Soliman, K.F. (1995) Behavioral and neurochemical changes in the dopaminergic system after repeated cocaine administration. Mol. Neurobiol., 11, 55-66.

Daunais, J.B. \& McGinty, J.F. (1995) Cocaine binges differentially alter striatal preprodynorphin and zif/268 mRNAs. Mol Brain Res, 29, 201-210.

De Vries, T.J., Schoffelmeer, A.N., Binnekade, R., Raaso, H. \& Vanderschuren, L.J. (2002) Relapse to cocaine- and heroin-seeking behavior mediated by dopamine $\mathrm{D}_{2}$ receptors is time-dependent and associated with behavioral sensitization. Neuropsychopharmacology, 26, 18-26.

Farfel, G.M., Kleven, M.S., Woolverton, W.L., Seiden, L.S. \& Perry, B.D. (1992) Effects of repeated injections of cocaine on catecholamine receptor binding sites, dopamine transporter binding sites and behavior in rhesus monkey. Brain Res, 578, 235-243.

Foltin, R.W., Ward, A.S., Haney, M., Hart, C.L. \& Collins, E.D. (2003) The effects of escalating doses of smoked cocaine in humans. Drug Alcohol Depend., 70, 149-157.

Gackenheimer, S.L., Schaus, J.M. \& Gehlert, D.R. (1995) $\left[{ }^{3} H\right]$-quinelorane binds to $D_{2}$ and $\mathrm{D}_{3}$ dopamine receptors in the rat brain. J. Pharmacol. Exp. Ther., 274, 1558-1565.

Gainetdinov, R.R., Bohn, L.M., Sotnikova, T.D., Cyr, M., Laakso, A., Macrae, A.D., Torres, G.E., Kim, K.M., Lefkowitz, R.J., Caron, M.G. \& Premont, R.T. (2003) Dopaminergic supersensitivity in G protein-coupled receptor kinase 6-deficient mice. Neuron, 38, 291-303.

Goeders, N.E. \& Kuhar, M.J. (1987) Chronic cocaine administration induces opposite changes in dopamine receptors in the striatum and nucleus accumbens. Alcohol Drug Res., 7, 207-216.

Heidbreder, C.A., Schenk, S., Partridge, B. \& Shippenberg, T.S. (1998) Increased responsiveness of mesolimbic and mesostriatal dopamine neurons to cocaine following repeated administration of a selective kappa-opioid receptor agonist. Synapse, 30, 255-262. 
Hitri, A., Little, K.Y. \& Ellinwood, E.H., Jr. (1996) Effect of cocaine on dopamine transporter receptors depends on routes of chronic cocaine administration. Neuropsychopharmacology, 14, 205-210.

Hurd, Y.L. \& Herkenham, M. (1993) Molecular alterations in the neostriatum of human cocaine addicts. Synapse, 13, 357-369.

Javitch, J.A., Strittmatter, S.M. \& Snyder, S.H. (1985) Differential visualization of dopamine and norepinephrine uptake sites in rat brain using $\left[{ }^{3} \mathrm{H}\right]$ mazindol autoradiography. $J$.

Neurosci., 5, 1513-1521.

Kitchen, I., Slowe, S., Matthes, H. \& Kieffer, B. (1997) Quantitative autoradiographic mapping of $\mu, \delta$ and $\kappa$ opioid receptors in knockout mice lacking the $\mu$-opioid receptor gene. Brain Res., 778, 73-88.

Koob, G. \& Kreek, M.J. (2007) Stress, dysregulation of drug reward pathways, and the transition to drug dependence. Am. J. Psychiatry, 164, 1149-1159.

Kula, N.S. \& Baldessarini, R.J. (1991) Lack of increase in dopamine transporter binding or function in rat brain tissue after treatment with blockers of neuronal uptake of dopamine. Neuropharmacology, 30, 89-92.

Kunko, P.M., Loeloff, R.J. \& Izenwasser, S. (1997) Chronic administration of the selective dopamine uptake inhibitor GBR 12,909, but not cocaine, produces marked decreases in dopamine transporter density. Naunyn Schmiedebergs Arch. Pharmacol., 356, 562-569.

Lena, I., Matthes, H., Kieffer, B. \& Kitchen, I. (2004) Quantitative autoradiography of dopamine receptors in the brains of $\mu$-opioid receptor knockout mice. Neurosci. Lett., 356, 220-224.

Little, K.Y., Kirkman, J.A., Carroll, F.I., Clark, T.B. \& Duncan, G.E. (1993) Cocaine use increases [3H]WIN 35428 binding sites in human striatum. Brain Res., 628, 17-25.

Little, K.Y., McLaughlin, D.P., Zhang, L., Livermore, C.S., Dalack, G.W., McFinton, P.R., DelProposto, Z.S., Hill, E., Cassin, B.J., Watson, S.J. \& Cook, E.H. (1998a) Cocaine, ethanol, and genotype effects on human midbrain serotonin transporter binding sites and mRNA levels. Am. J. Psychiatry, 155, 207-213.

Little, K.Y., McLaughlin, D.P., Zhang, L., McFinton, P.R., Dalack, G.W., Cook, E.H., Jr., Cassin, B.J. \& Watson, S.J. (1998b) Brain dopamine transporter messenger RNA and binding sites in cocaine users: a postmortem study. Arch. Gen. Psychiatry, 55, 793-799.

Little, K.Y., Zhang, L., Desmond, T., Frey, K.A., Dalack, G.W. \& Cassin, B.J. (1999) Striatal dopaminergic abnormalities in human cocaine users. Am. J. Psychiatry, 156, 238-245.

Maggos, C.E., Spangler, R., Zhou, Y., Schlussman, S.D., Ho, A. \& Kreek, M.J. (1997) Quantitation of dopamine transporter mRNA in the rat brain: mapping, effects of "binge" cocaine administration and withdrawal. Synapse, 26, 55-61.

Maggos, C.E., Tsukada, H., Kakiuchi, T., Nishiyama, S., Myers, J.E., Kreuter, J., Schlussman, S.D., Unterwald, E.M., Ho, A. \& Kreek, M.J. (1998) Sustained withdrawal allows normalization of in vivo $\left[{ }^{11} \mathrm{C}\right] \mathrm{N}$-methylspiperone dopamine $\mathrm{D}_{2}$ receptor binding after chronic binge cocaine: a positron emission tomography study in rats.

Neuropsychopharmacol, 19, 146-153.

Mantsch, J.R., Yuferov, V., Mathieu-Kia, A.M., Ho, A. \& Kreek, M.J. (2003)

Neuroendocrine alterations in a high-dose, extended-access rat self-administration model of escalating cocaine use. Psychoneuroendocrinology, 28, 836-862.

Mash, D.C., Pablo, J., Ouyang, Q., Hearn, W.L. \& Izenwasser, S. (2002) Dopamine transport function is elevated in cocaine users. J. Neurochem., 81, 292-300.

Mayfield, R.D. \& Zahniser, N.R. (2001) Dopamine D2 receptor regulation of the dopamine transporter expressed in Xenopus laevis oocytes is voltage-independent. Mol. Pharmacol., 59, 113-121. 
Moore, R.J., Vinsant, S.L., Nader, M.A., Porrino, L.J. \& Friedman, D.P. (1998) Effect of cocaine self-administration on dopamine D2 receptors in rhesus monkeys. Synapse, 30, 8896.

Nader, M.A. \& Czoty, P.W. (2005) PET imaging of dopamine D2 receptors in monkey models of cocaine abuse: genetic predisposition versus environmental modulation. Am. J. Psychiatry, 162, 1473-1482.

Nader, M.A., Daunais, J.B., Moore, T., Nader, S.H., Moore, R.J., Smith, H.R., Friedman, D.P. \& Porrino, L.J. (2002) Effects of cocaine self-administration on striatal dopamine systems in rhesus monkeys: initial and chronic exposure. Neuropsychopharmacology, 27, 35-46.

Nader, M.A., Morgan, D., Gage, H.D., Nader, S.H., Calhoun, T.L., Buchheimer, N., Ehrenkaufer, R. \& Mach, R.H. (2006) PET imaging of dopamine D2 receptors during chronic cocaine self-administration in monkeys. Nat. Neurosci., 9, 1050-1056.

Nestler, E.J., Terwilliger, R.Z., Walker, J.R., Sevarino, K.A. \& Duman, R.S. (1990) Chronic cocaine treatment decreases levels of the $\mathrm{G}$ protein subunits $\mathrm{Gi}$ alpha and Go alpha in discrete regions of rat brain. J. Neurochem., 55, 1079-1082.

Newman-Tancredi, A., Cussac, D., Brocco, M., Rivet, J.M., Chaput, C., Touzard, M., Pasteau, V. \& Millan, M.J. (2001) Dopamine D2 receptor-mediated G-protein activation in rat striatum: functional autoradiography and influence of unilateral 6-hydroxydopamine lesions of the substantia nigra. Brain Res., 920, 41-54.

Parsons, L.H., Schad, C.A. \& Justice, J.B., Jr. (1993) Co-administration of the D2 antagonist pimozide inhibits up-regulation of dopamine release and uptake induced by repeated cocaine. J. Neurochem., 60, 376-379.

Peris, J., Boyson, S.J., Cass, W.A., Curella, P., Dwoskin, L.P., Larson, G., Lin, L.H., Yasuda, R.P. \& Zahniser, N.R. (1990) Persistence of neurochemical changes in dopamine systems after repeated cocaine administration. J. Pharmacol. Exp. Ther., 253, 38-44.

Pilotte, N.S., Sharpe, L.G. \& Kuhar, M.J. (1994) Withdrawal of repeated intravenous infusions of cocaine persistently reduces binding to dopamine transporters in the nucleus accumbens of Lewis rats. J. Pharmacol. Exp. Ther., 269, 963-969.

Pilotte, N.S., Sharpe, L.G., Rountree, S.D. \& Kuhar, M.J. (1996) Cocaine withdrawal reduces dopamine transporter binding in the shell of the nucleus accumbens. Synapse, 22, 87-92.

Schlussman, S.D., Zhang, Y., Kane, S., Stewart, C.L., Ho, A. \& Kreek, M.J. (2003) Locomotion, stereotypy, and dopamine $\mathrm{D}_{1}$ receptors after chronic "binge" cocaine in C57BL/6J and 129/J mice. Pharmacol. Biochem. Behav., 75, 123-131.

Schlussman, S.D., Zhou, Y., Bailey, A., Ho, A. \& Kreek, M.J. (2005) Steady-dose and escalating-dose "binge" administration of cocaine alter expression of behavioral stereotypy and striatal preprodynorphin mRNA levels in rats. Brain Res. Bull., 67, 169-175.

Schroeder, J.A., Niculescu, M. \& Unterwald, E.M. (2003) Cocaine alters mu but not delta or kappa opioid receptor-stimulated in situ $\left[{ }^{35} \mathrm{~S}\right] \mathrm{GTP}$ gammaS binding in rat brain. Synapse, 47 , 26-32.

Seeman, P., McCormick, P.N. \& Kapur, S. (2007) Increased dopamine D2(High) receptors in amphetamine-sensitized rats, measured by the agonist $[(3) \mathrm{H}](+) \mathrm{PHNO}$. Synapse, 61, 263267.

Sharpe, L.G., Pilotte, N.S., Mitchell, W.M. \& De Souza, E.B. (1991) Withdrawal of repeated cocaine decreases autoradiographic $\left[{ }^{3} \mathrm{H}\right]$ mazindol-labelling of dopamine transporter in rat nucleus accumbens. Eur. J. Pharmacol., 203, 141-144.

Spanagel, R. (1995) Modulation of drug-induced sensitization processes by endogenous opioid systems. Behav. Brain Res., 70, 37-49.

Staley, J.K., Hearn, W.L., Ruttenber, A.J., Wetli, C.V. \& Mash, D.C. (1994) High affinity cocaine recognition sites on the dopamine transporter are elevated in fatal cocaine overdose victims. J. Pharmacol. Exp. Ther., 271, 1678-1685. 
Taylor, D.L., Ho, B.T. \& Fagan, J.D. (1979) Increased dopamine receptor binding in rat brain by repeated cocaine injections. Commun. Psychopharmacol., 3, 137-142.

Tsukada, H., Kreuter, J., Maggos, C.E., Unterwald, E.M., Kakiuchi, T., Nishiyama, S., Futatsubashi, M. \& Kreek, M.J. (1996) Effects of binge pattern cocaine administration on dopamine $\mathrm{D}_{1}$ and $\mathrm{D}_{2}$ receptors in the rat brain: an in vivo study using positron emission tomography. J. Neurosci., 16, 7670-7677.

Ujike, H., Akiyama, K. \& Otsuki, S. (1990) D-2 but not D-1 dopamine agonists produce augmented behavioral response in rats after subchronic treatment with methamphetamine or cocaine. Psychopharmacology (Berl), 102, 459-464.

Unterwald, E.M., Ho, A., Rubenfeld, J.M. \& Kreek, M.J. (1994) Time course of the development of behavioral sensitization and dopamine receptor up-regulation during binge cocaine administration. J. Pharmacol. Exp. Ther., 270, 1387-1396.

Uslaner, J.M., Crombag, H.S., Ferguson, S.M. \& Robinson, T.E. (2003) Cocaine-induced psychomotor activity is associated with its ability to induce c-fos mRNA expression in the subthalamic nucleus: effects of dose and repeated treatment. Eur. J. Neurosci., 17, 21802186.

Volkow, N.D., Fowler, J.S., Wang, G.J., Hitzemann, R., Logan, J., Schlyer, D.J., Dewey, S.L. \& Wolf, A.P. (1993) Decreased dopamine $\mathrm{D}_{2}$ receptor availability is associated with reduced frontal metabolism in cocaine abusers. Synapse, 14, 169-177.

Volkow, N.D., Fowler, J.S., Wolf, A.P., Schlyer, D., Shiue, C.Y., Alpert, R., Dewey, S.L., Logan, J., Bendriem, B., Christman, D. \& et al. (1990) Effects of chronic cocaine abuse on postsynaptic dopamine receptors. Am. J. Psychiatry, 147, 719-724.

Wilson, J.M., Nobrega, J.N., Carroll, M.E., Niznik, H.B., Shannak, K., Lac, S.T., Pristupa, Z.B., Dixon, L.M. \& Kish, S.J. (1994a) Heterogeneous subregional binding patterns of ${ }^{3} \mathrm{H}-$ WIN 35,428 and 3H-GBR 12,935 are differentially regulated by chronic cocaine selfadministration. J. Neurosci., 14, 2966-2979.

Wilson, J.M., Nobrega, J.N., Corrigall, W.A., Coen, K.M., Shannak, K. \& Kish, S.J. (1994b) Amygdala dopamine levels are markedly elevated after self- but not passive-administration of cocaine. Brain Res., 668, 39-45.

Zorrilla, E.P., Valdez, G.R. \& Weiss, F. (2001) Changes in levels of regional CRF-likeimmunoreactivity and plasma corticosterone during protracted drug withdrawal in dependent rats. Psychopharmacology (Berl), 158, 374-381. 
Fig. 1 a) Escalating dose

Day 1 (15 x 3 mg/kg/day)

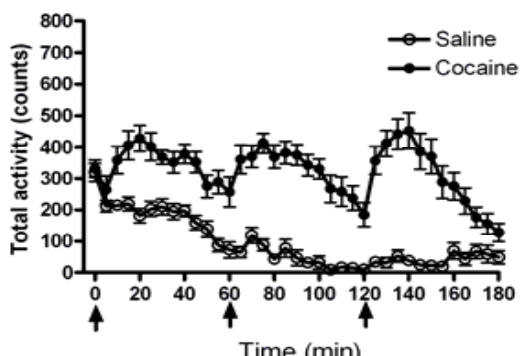

Day 9 (25 x 3 mg/kg/day)

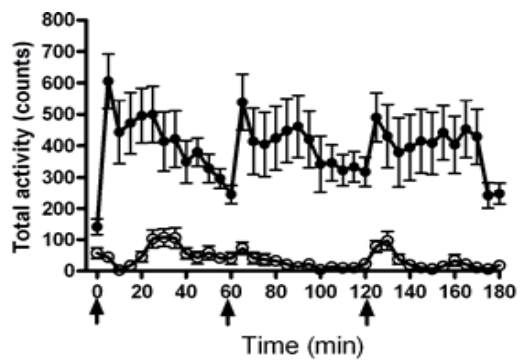

b) Steady dose

Day 1 (15 x 3 mg/kg/day)

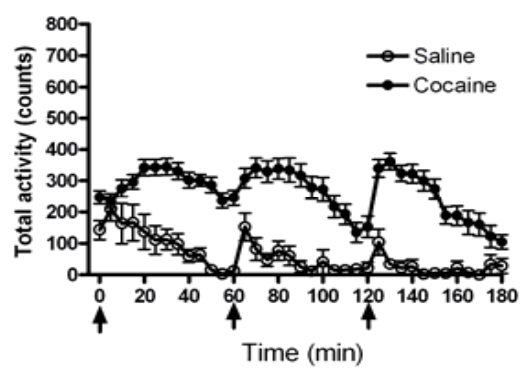

Day 9 (15 x 3 mg/kg/day)

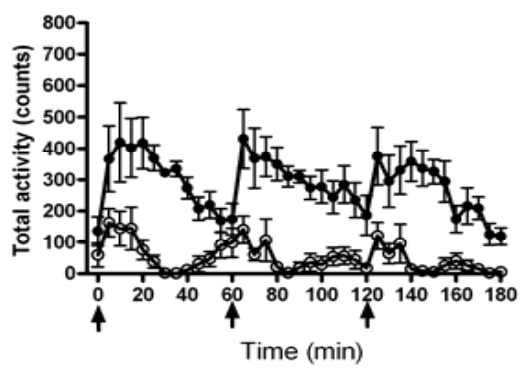

Day 3 (15 x 3 mg/kg/day)

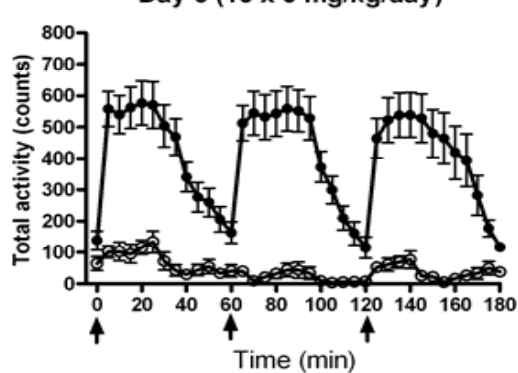

Day 13 (30 x 3 mg/kg/day)

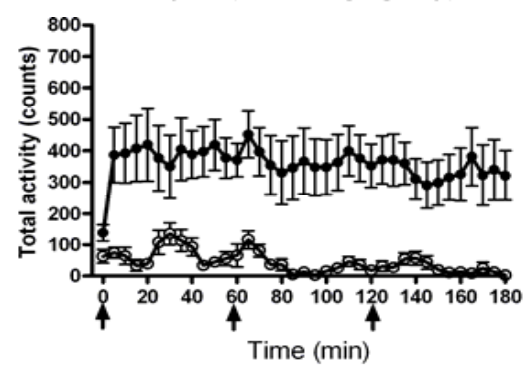

Day 3 (15 x 3 mg/kg/day)

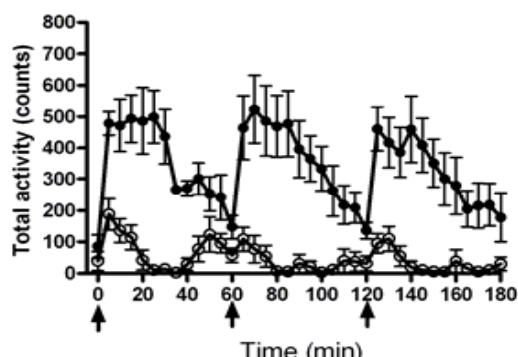

Day 13 (15 x 3 mg/kg/day)

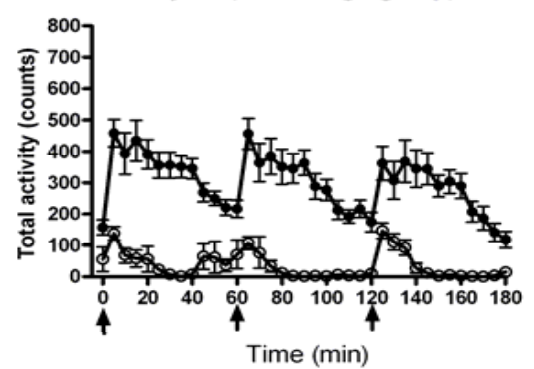

Day 5 (20 x 3 mg/kg/day)

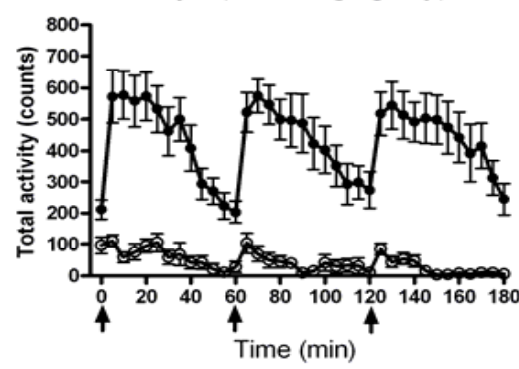

acute (30 $\times 3 \mathrm{mg} / \mathrm{kg} /$ day)

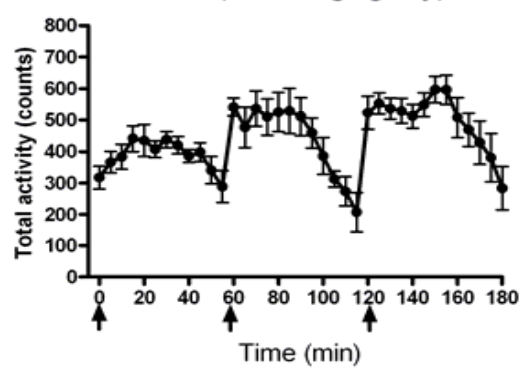

Day 5 (15 x 3 mg/kg/day)

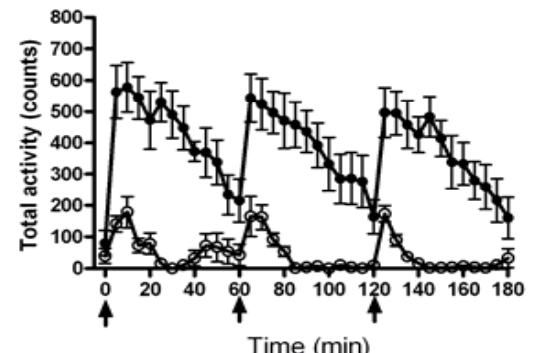

Time (min) 
Fig. 2

a) Escalating dose

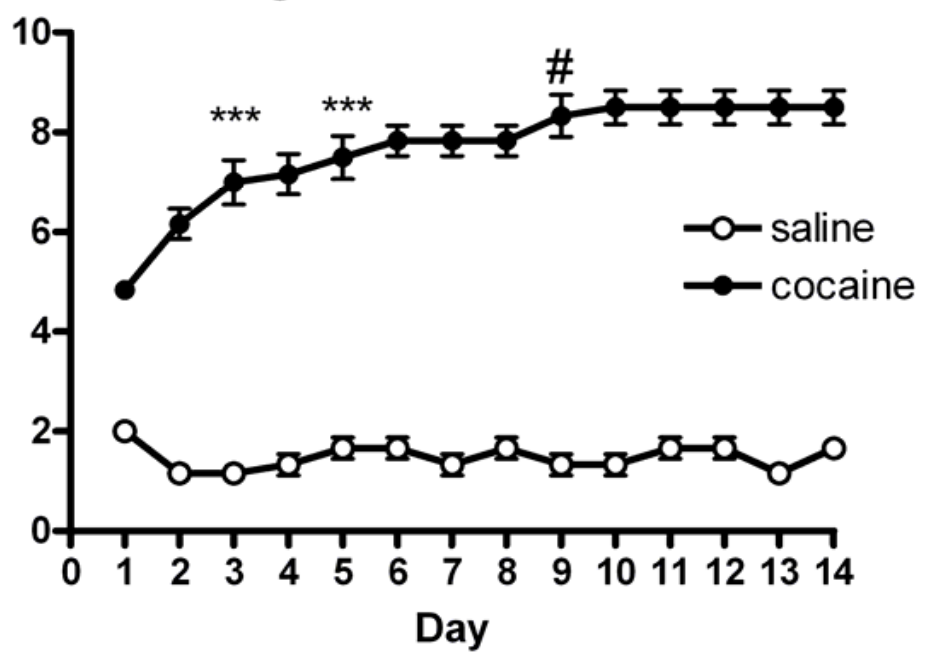

b) Steady dose

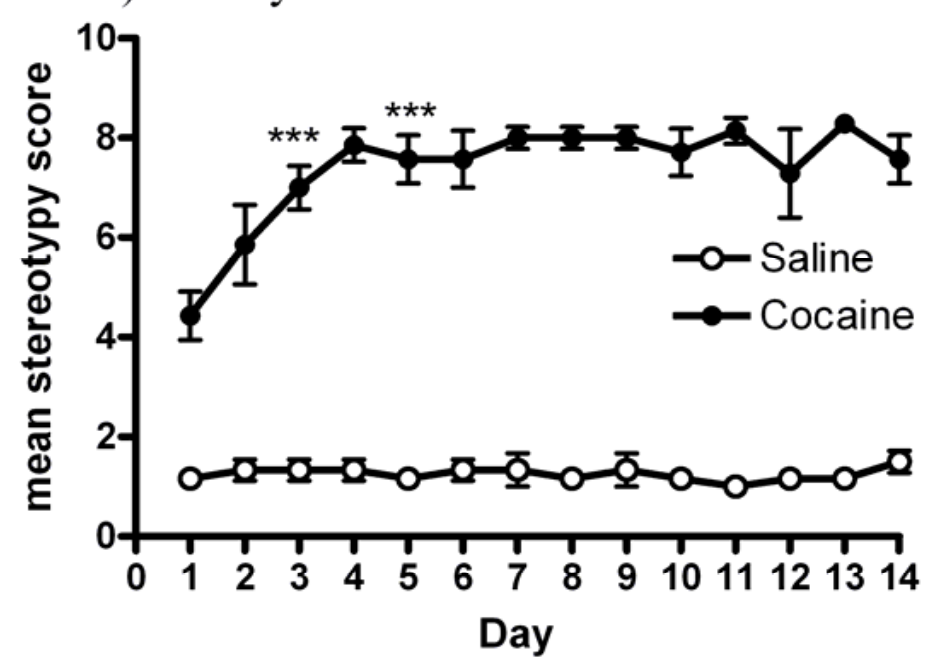


Fig. 3

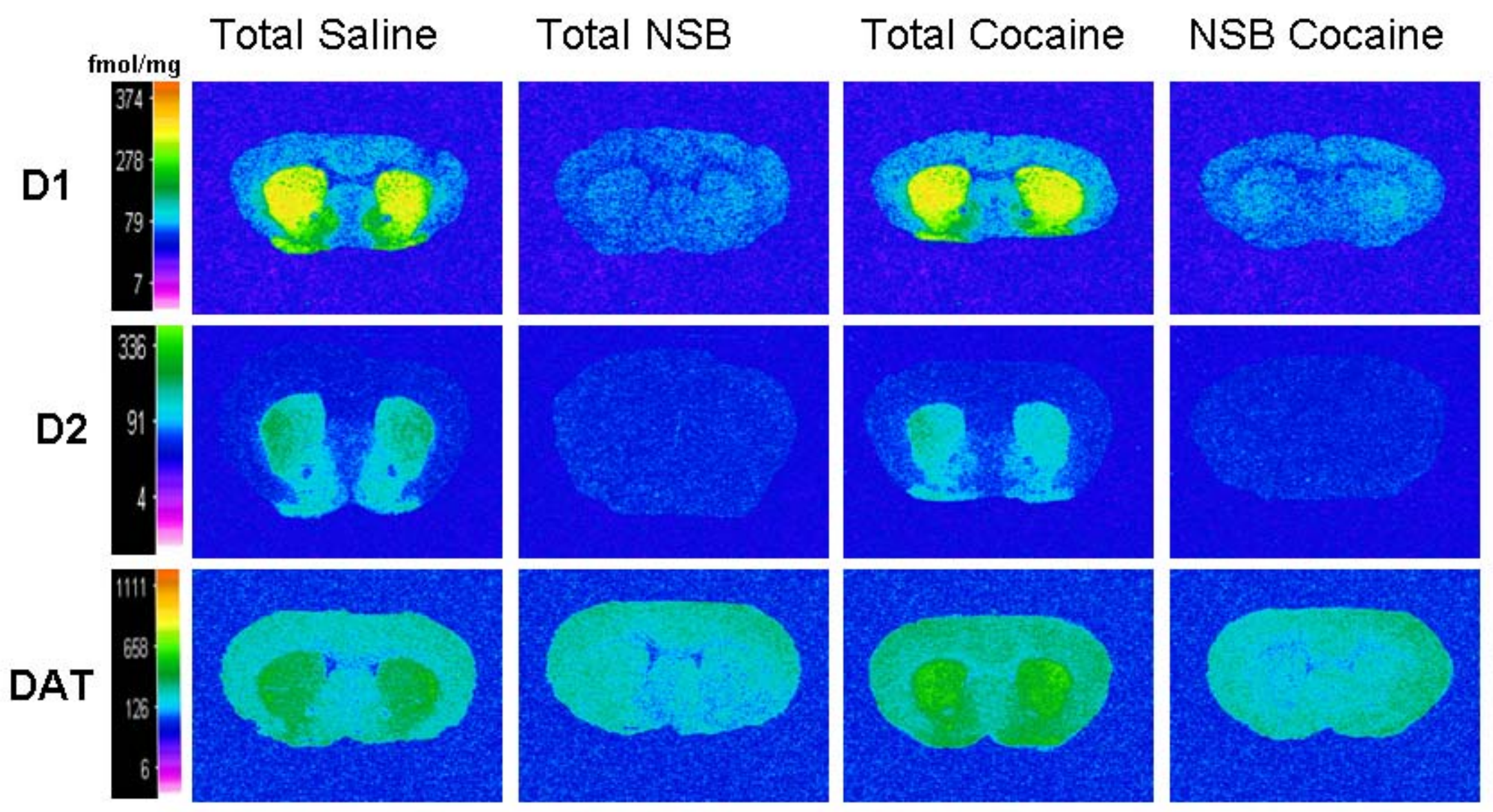


Fig. 4
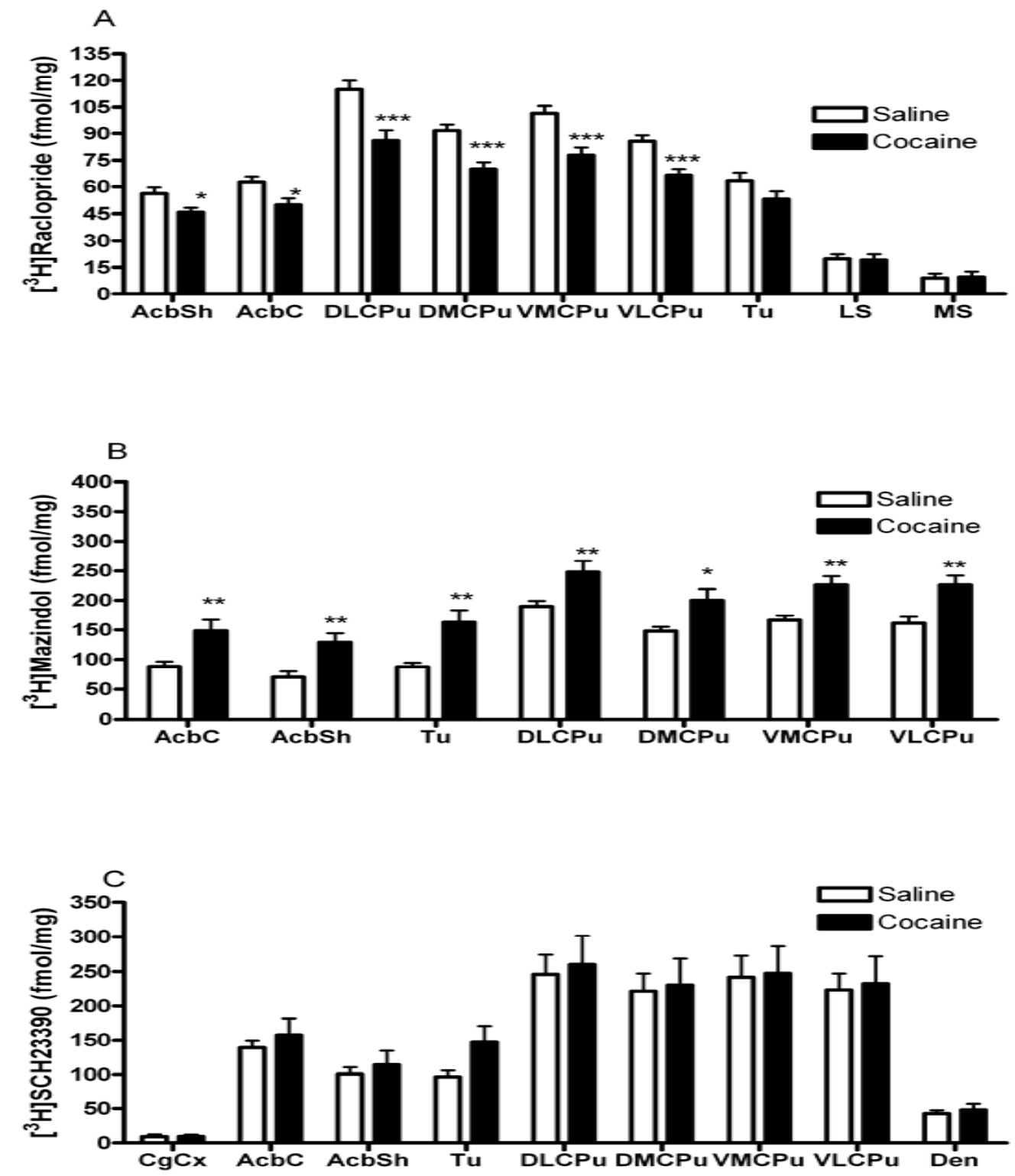
Fig. 5.

Saline

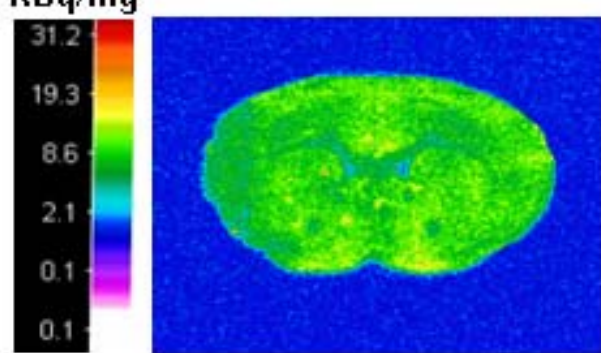

Cocaine

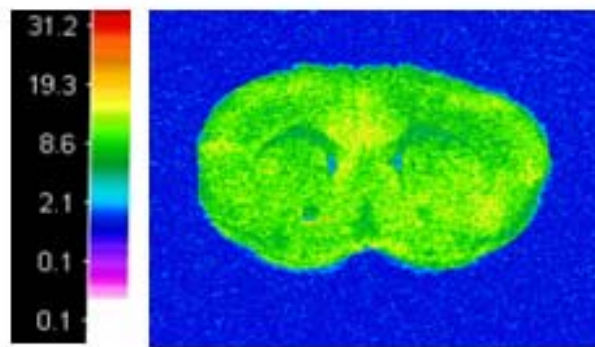

Quinrolane Stimulated
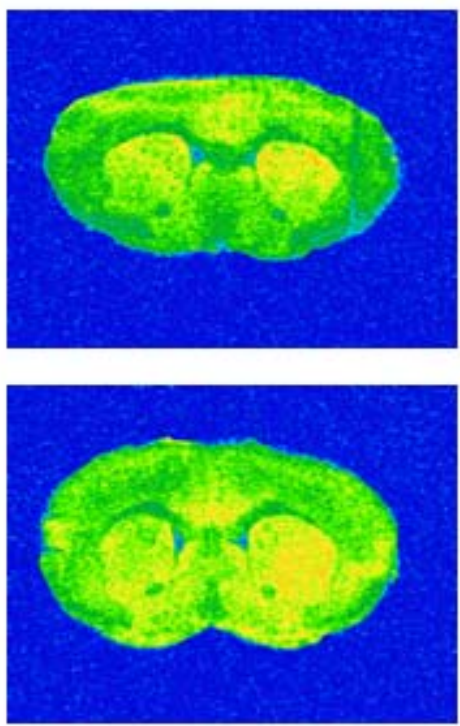

Reversal
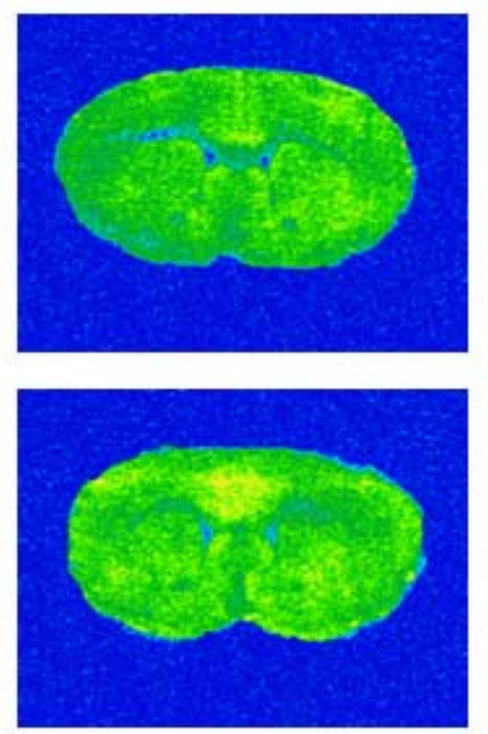

NSB
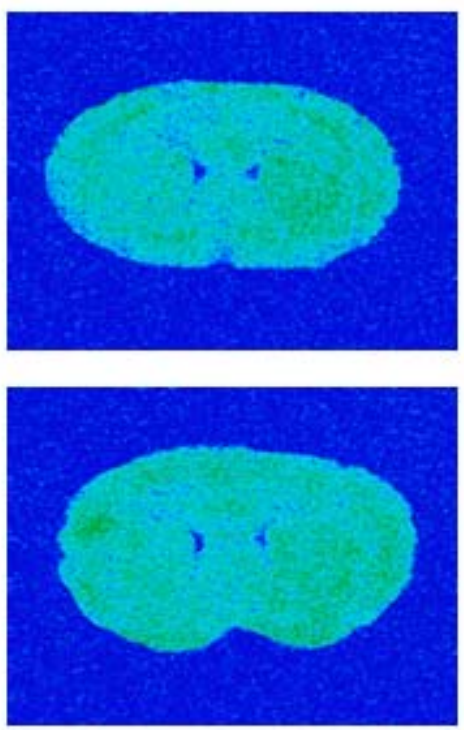
Fig6

a. Escalating dose

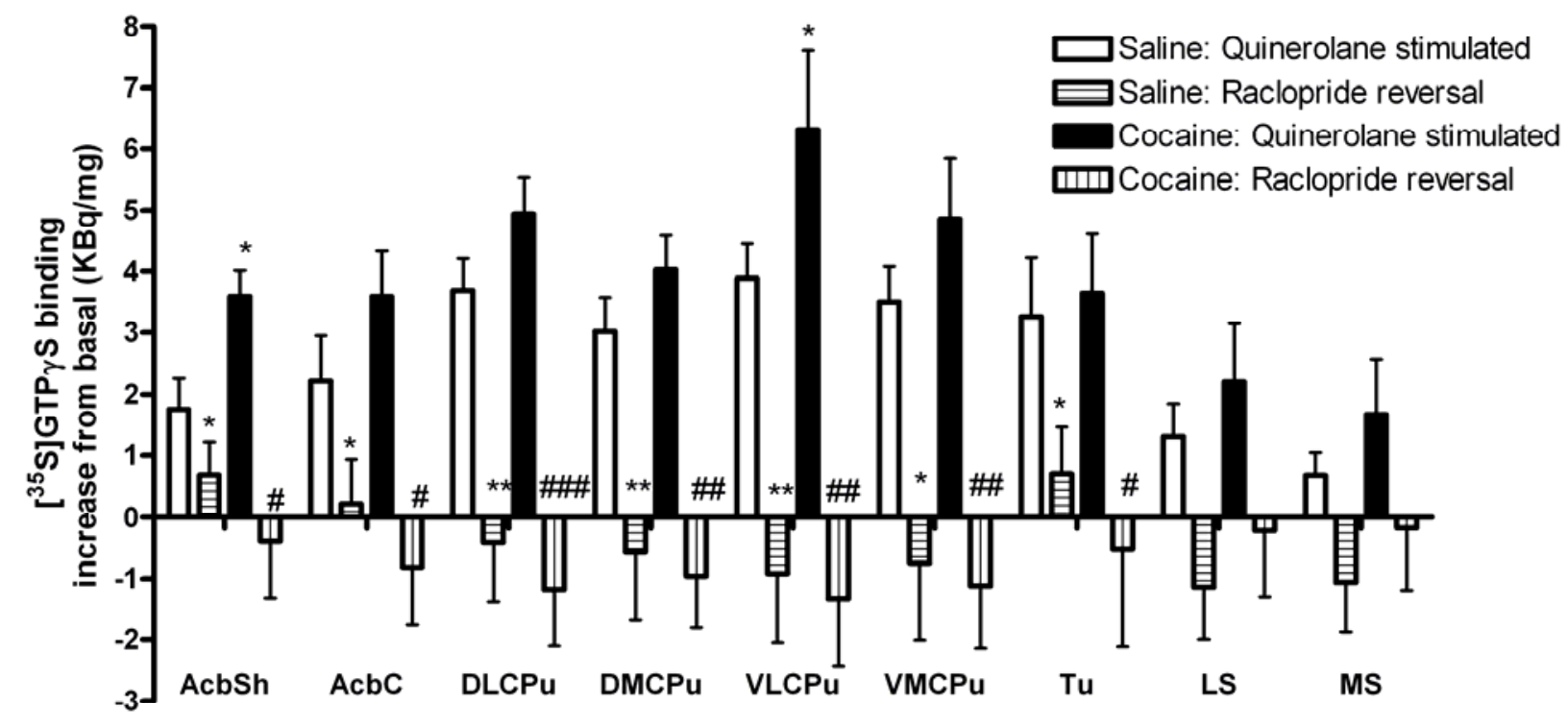

b. Steady dose

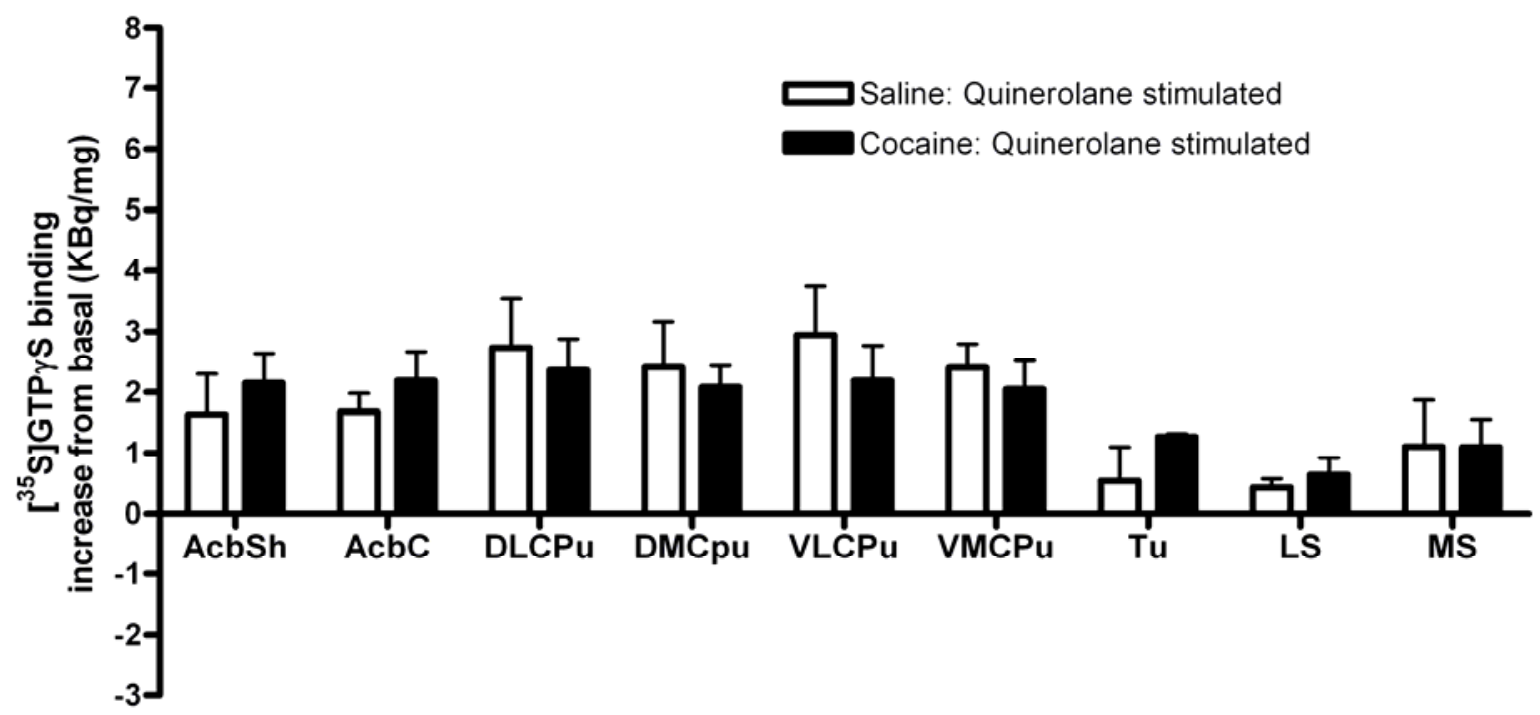

